University of Nebraska - Lincoln

DigitalCommons@University of Nebraska - Lincoln

2015

Decadal re-evaluation of contaminant exposure and productivity of ospreys (Pandion haliaetus) nesting in Chesapeake Bay Regions of Concern

\author{
Rebecca S. Lazarus \\ U.S. Geological Survey \\ Barnett A. Rattner \\ United States Geological Survey, brattner@usgs.gov \\ Peter C. McGowan \\ U.S. Fish and Wildlife Service \\ Robert C. Hale \\ Virginia Institute of Marine Science \\ Sandra L. Schultz \\ U.S. Geological Survey
}

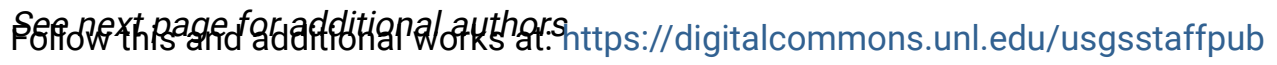

Part of the Geology Commons, Oceanography and Atmospheric Sciences and Meteorology Commons, Other Earth Sciences Commons, and the Other Environmental Sciences Commons

Lazarus, Rebecca S.; Rattner, Barnett A.; McGowan, Peter C.; Hale, Robert C.; Schultz, Sandra L.; KarounaRenier, Natalie K.; and Ottinger, Mary Ann, "Decadal re-evaluation of contaminant exposure and productivity of ospreys (Pandion haliaetus) nesting in Chesapeake Bay Regions of Concern" (2015). USGS Staff -- Published Research. 957.

https://digitalcommons.unl.edu/usgsstaffpub/957

This Article is brought to you for free and open access by the US Geological Survey at DigitalCommons@University of Nebraska - Lincoln. It has been accepted for inclusion in USGS Staff -- Published Research by an authorized administrator of DigitalCommons@University of Nebraska - Lincoln. 


\section{Authors}

Rebecca S. Lazarus, Barnett A. Rattner, Peter C. McGowan, Robert C. Hale, Sandra L. Schultz, Natalie K. Karouna-Renier, and Mary Ann Ottinger 


\title{
Decadal re-evaluation of contaminant exposure and productivity of ospreys (Pandion haliaetus) nesting in Chesapeake Bay Regions of Concern
}

\author{
Rebecca S. Lazarus a, b, Barnett A. Rattner ${ }^{\text {a, * }}$, Peter C. McGowan ${ }^{\text {c }}$, Robert C. Hale ${ }^{\text {, }}$ \\ Sandra L. Schultz ${ }^{a}$, Natalie K. Karouna-Renier ${ }^{\mathrm{a}}$, Mary Ann Ottinger ${ }^{\mathrm{b}, 1}$ \\ ${ }^{a}$ U.S. Geological Survey, Patuxent Wildlife Research Center, Beltsville, MD 20705, USA \\ ${ }^{\mathrm{b}}$ Marine-Estuarine Environmental Sciences Program and Department of Animal and Avian Sciences, University of Maryland, College Park, MD 20742, USA \\ c U.S. Fish and Wildlife Service, Chesapeake Bay Field Office, Annapolis, MD 21401, USA \\ d Virginia Institute of Marine Science, College of William and Mary, Gloucester Point, VA 23062, USA
}

\section{A R T I C L E I N F O}

\section{Article history:}

Received 30 March 2015

Received in revised form

19 May 2015

Accepted 28 May 2015

Available online 24 June 2015

\section{Keywords:}

Chesapeake Bay

Genotoxicity

Osprey

Persistent pollutants

Productivity

\begin{abstract}
A B S T R A C T
The last large-scale ecotoxicological study of ospreys (Pandion haliaetus) in Chesapeake Bay was conducted in 2000-2001 and focused on U.S. EPA-designated Regions of Concern (ROCs; Baltimore Harbor/ Patapsco, Anacostia/middle Potomac, and Elizabeth Rivers). In 2011-2012, ROCs were re-evaluated to determine spatial and temporal trends in productivity and contaminants. Concentrations of $p, p^{\prime}$-DDE were low in eggs and below the threshold associated with eggshell thinning. Eggs from the Anacostia/ middle Potomac Rivers had lower total PCB concentrations in 2011 than in 2000; however, concentrations remained unchanged in Baltimore Harbor. Polybrominated diphenyl ether flame retardants declined by $40 \%$, and five alternative brominated flame retardants were detected at low levels. Osprey productivity was adequate to sustain local populations, and there was no relation between productivity and halogenated contaminants. Our findings document continued recovery of the osprey population, declining levels of many persistent halogenated compounds, and modest evidence of genetic damage in nestlings from industrialized regions.
\end{abstract}

Published by Elsevier Ltd.

\section{Introduction}

The Chesapeake Bay is the largest estuary in the United States and supports a diversity of avian species. Degradation of habitat quality by a mixture of agricultural, industrial and urban pollution continues to threaten the most vulnerable portions of the estuary, and jeopardize fish and wildlife health. Globally, the largest nesting osprey (Pandion haliaetus) population is found in the Chesapeake Bay, which has been nicknamed the "osprey garden of the world" (Poole, 1989). Ospreys are used as ecological sentinels of environmental health due to their high trophic level, widespread

\footnotetext{
* Corresponding author. Patuxent Wildlife Research Center, U.S. Geological Survey, c/o BARC-East, Building 308, 10300 Baltimore Avenue, Beltsville, MD 20705, USA.

E-mail address: brattner@usgs.gov (B.A. Rattner).

1 Present address: Department of Biology and Biochemistry, University of Houston, Houston, TX 77004, USA
}

distribution and nest-site fidelity (Grove et al., 2009; Henny et al., 2010).

The Chesapeake Bay osprey population has been extensively studied since the 1970s. In 1973, the osprey population was estimated to be only 1450 nesting pairs, and only seven pairs were observed north of the Chesapeake Bay Bridge (near Annapolis, MD) to the Susquehanna River (Henny et al., 1974). With the banning of the pesticide DDT in 1972, the osprey population rebounded both numerically and spatially. A bay-wide survey in 1995-1996 estimated 3500 nesting pairs, and population growth was rapid in the tidal freshwater tributaries and areas north of the Chesapeake Bay Bridge (Watts et al., 2004).

For decades, impaired water quality and toxic chemicals in sediment, water and biota have been found in highly industrialized and urbanized areas of Chesapeake Bay including Baltimore Harbor and the Anacostia and Elizabeth Rivers. These three sites have been designated by the U.S. Environmental Protection Agency (US EPA) as Regions of Concern (ROCs) (US EPA, 1994). Rattner et al. (2004) 
reported that osprey productivity in these regions was marginally adequate to sustain local populations. Although concentrations of $p, p$ '-DDE and other organochlorine pesticides declined in eggs, PCB levels remained elevated especially in Baltimore Harbor compared to reference sites. Polybrominated diphenyl ethers (PBDEs) were detected in osprey eggs from all sites, with values being some of the greatest found in North America. All ROCs continue to have human health advisories on the consumption of several fish and shellfish species due to contamination with PCBs and other pesticides (VDH, 2009; MDE, 2014).

In May 2009, the Chesapeake Bay Executive Order 13508 was signed, which placed emphasis on continued monitoring of ROCs and the restoration and protection of the Bay (Chesapeake Bay Executive Order, 2009). Just over a decade has elapsed since the last large-scale ecotoxicological monitoring study of Chesapeake Bay wildlife, during which time there were limited exposure data for Bay avifauna (Rattner and McGowan, 2007; Chen et al., 2010; US EPA, 2012). As part of a larger study examining contaminant exposure, food web transfer, and potential effects on ospreys in Chesapeake Bay, the three historical ROCs were re-visited to examine temporal and spatial changes in osprey productivity and concentrations of legacy and more contemporary pollutants.

\section{Materials and methods}

\subsection{Study sites}

Ospreys nesting on navigational markers, platforms, duck blinds, and other accessible structures were sampled during their nesting seasons from March through July of 2011 and 2012. Sampling was conducted in Chesapeake ROCs including (i) Baltimore Harbor/Patapsco River in MD (2011, $\mathrm{n}=7$ ), (ii) the Anacostia/ middle Potomac Rivers in parts of Washington, D.C., Maryland, and Virginia (2011, $\mathrm{n}=9$ ), and (iii) the Elizabeth River in Virginia (2012, $\mathrm{n}=6$ ) (Fig. 1). These sites encompassed urban and industrial gradients along a $20-25 \mathrm{~km}$ stretch of each river. The Paul S. Sarbanes Ecosystem Restoration Project at Poplar Island, MD (hereafter, Poplar Island), a remote mid-Bay location, was used as a reference site (2011-2012, $\mathrm{n}=4$ eggs/year). Notably, results from a 2010 common tern (Sterna hirundo) egg collection at Poplar Island indicated low levels of organochlorine pesticides, non-coplanar PCBs, and PBDEs (Rattner et al., 2013), making it a more suitable reference site than the South, West and Rhode Rivers that were used in 2000-2001 (Rattner et al., 2004). In 2011-2012, nests in ROCs were strategically selected near those nests previously studied. All procedures involving ospreys were conducted under

\section{Poplar Island}

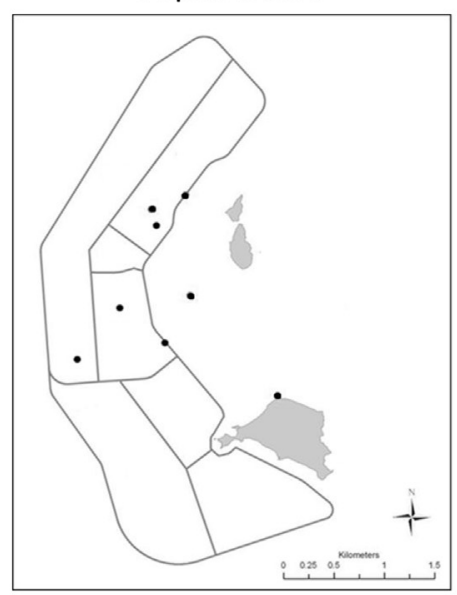

Baltimore Harbor/ Patapsco River

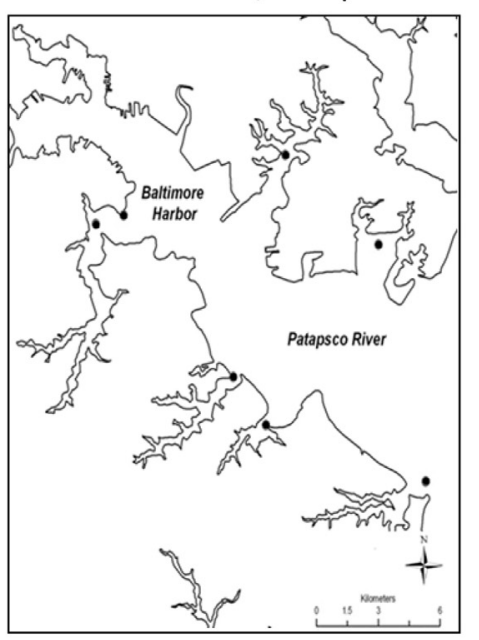

Chesapeake Bay

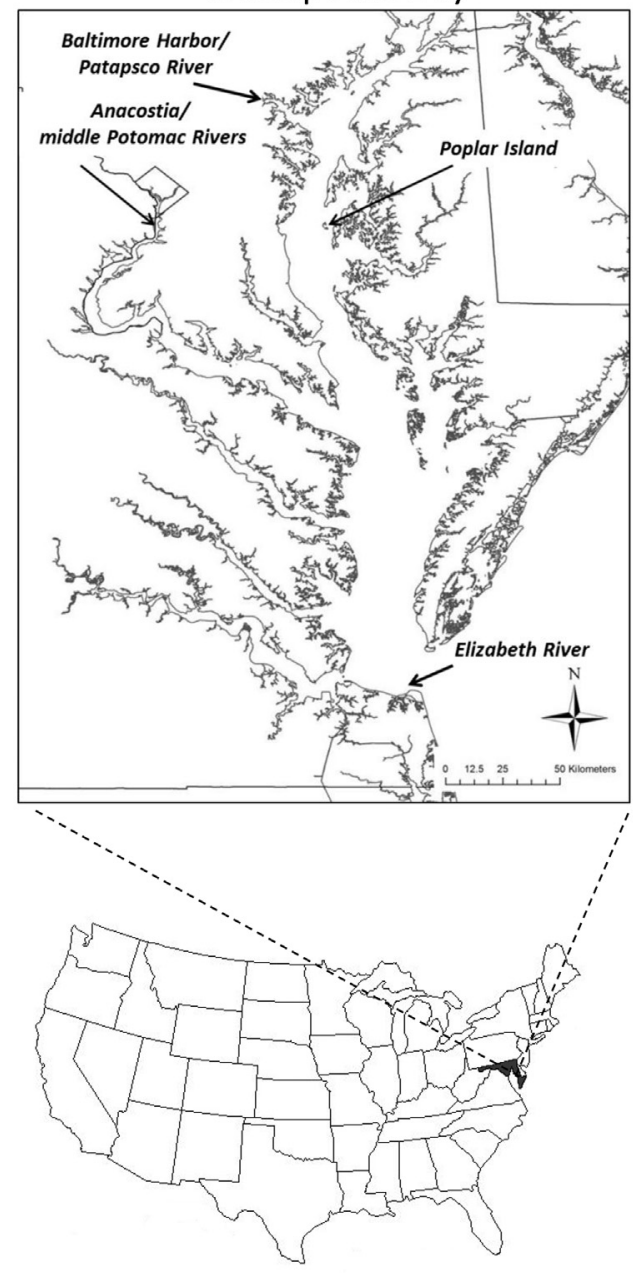

Anacostia/middle Potomac Rivers

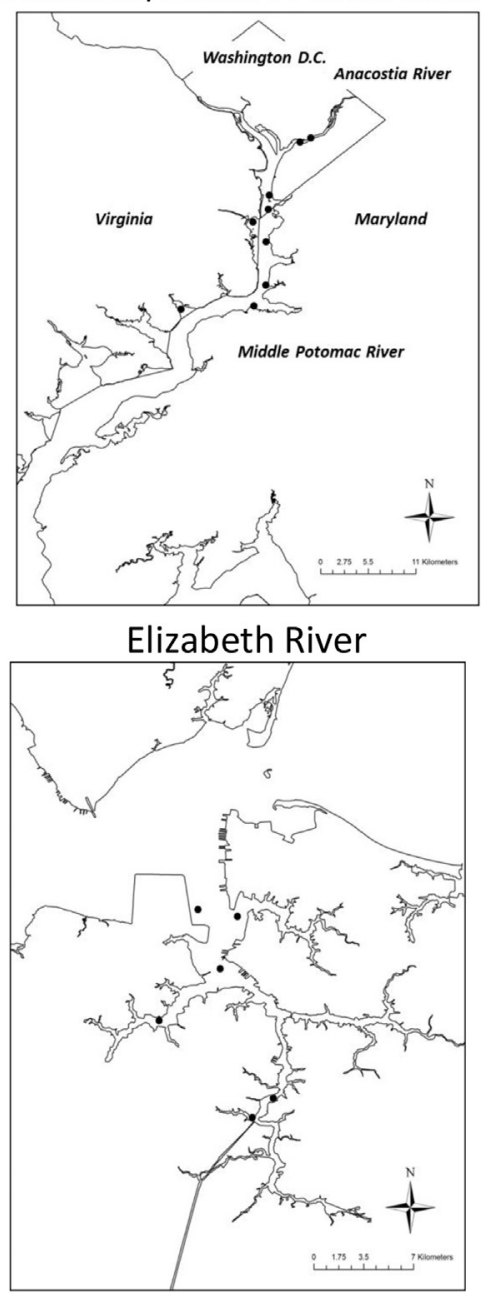

Fig. 1. Locations of sampled osprey nests in Chesapeake Bay Regions of Concern and Poplar Island reference site, ( 
approval of the Institutional Animal Care and Use Committees of the USGS-Patuxent Wildlife Research Center (USGS-PWRC) and the University of Maryland, and with appropriate Federal and State scientific collection permits.

\subsection{Egg sample collection}

Using the sample egg technique described in Blus (1984), osprey eggs were collected for residue analysis ( $\mathrm{n}=30$ total). After each clutch was complete (three or more eggs), a random egg was sampled within a week for subsequent contaminant analysis. Eggs were transported to the USGS-PWRC, cleaned with distilled water, weighed and their length and breadth were measured to the nearest $0.01 \mathrm{~mm}$. A 2.4-mm hole was drilled into the blunt end of the egg (Dremel ${ }^{\circledR}$ MultiPro ${ }^{\circledR} 7.2$ V, Model 770, Mt. Prospect, IL, USA). Moisture loss during incubation concentrates contaminants in the egg. Distilled water was injected into the air cell to return moisture content and contaminant concentrations to those in the egg when it was freshly laid (Heinz et al., 2009). Eggs were weighed, opened to determine fertility and developmental stage, and contents transferred into a chemically clean jar (I-CHEM, VWR Scientific, Radnor, PA, USA), stored at $-80^{\circ} \mathrm{C}$, and eventually transported to the Virginia Institute of Marine Science (VIMS), Gloucester, VA, USA. Eggshells were dried for 3-4 months at room temperature and measured for thickness at three sites on the equator using a micrometer (Model 1010M; L.S. Starrett Co., Athol, MA, USA) and averaged.

\subsection{Osprey reproductive success}

Osprey productivity was monitored following the definitions and traditional methods described by Postupalsky (1977) and more recently Steenhof and Newton (2007). Initial nest visits were made in March to locate study nests and determine breeding status. Additional nests were monitored to have back-up locations for sampled nests if the targeted nests failed. Nests were visited at 7-10 day intervals to determine the fate of the nest including the numbers of eggs laid, eggs hatched, and young present at advanced age ( $>45$ days) to fledging. Other observations including evidence of predation or disturbance were noted.

\subsection{Osprey nestling blood samples and morphological endpoints}

A blood sample was collected from a 40-45-day-old nestling at each nest from which a sample egg was collected. In the event the target nest failed (8/30 instances), the sample was drawn from a nestling residing in a nearby nest (within $2.5 \mathrm{~km}$ ). Specifically, before fledging, one nestling per nest $(n=30)$ was removed from the nest for about $10 \mathrm{~min}$. Following physical examination, culmen length and body weight were measured and the crop was palpated to determine level of crop filling. A 5-7-mL brachial blood sample was drawn using a 23-gauge 1-inch needle into a heparinized syringe (Sarstedt International, Newton, NC, USA). About $100 \mu \mathrm{L}$ of fresh osprey nestling blood was transferred to a microcentrifuge tube, frozen on dry ice, and stored at $-80{ }^{\circ} \mathrm{C}$ for the DNA damage assay. The remainder of the blood sample was saved for a concurrent study (Lazarus et al., 2015).

\subsection{Analysis of contaminant residues in osprey eggs}

Osprey egg analyses for 11 PBDE congeners, 5 alternative brominated flame retardants [(alt-BFRs: $\alpha, \beta, \gamma$ hexabromocyclododecane (HBCD), 1,2-bis (2,4,6-tribromophenoxy) ethane (BTBPE), di(2-ethylhexyl)-2,3,4,5-tetrabromophthalate (TBPH), 2-ethylhexyl 2,3,4,5-tetrabromobenzoate (TBB), and decabromodiphenyl ether (DBDPE)], 129 PCB congeners, 44 organochlorine pesticides and methoxytriclosan were conducted based on the methods of Chen et al. (2008) and La Guardia et al. (2007, 2010). Egg contents were homogenized, lyophilized and then spiked with surrogate standards of PCB 30, 65 and 204 (Ultra Scientific, North Kingstown, RI, USA), ${ }^{13} \mathrm{C}$-methoxytriclosan, ${ }^{13} \mathrm{C}$ PCB-126 and 2,3,4,4',5,6 - hexabromodiphenyl ether (BDE 166; Cambridge Isotope Laboratories, Inc., Andover, MA, USA). Blanks, consisting of sodium sulfate (baked at $450{ }^{\circ} \mathrm{C}$ overnight), were analyzed to evaluate possible laboratory contamination. Dried samples underwent accelerated solvent extraction (Dionex ASE 200 , Sunnyvale, CA, USA) using methylene chloride (DCM) at $100^{\circ} \mathrm{C}$ and $68 \mathrm{~atm}$.

Extracts were purified by size exclusion chromatography (SEC, Envirosep-ABC ${ }^{\circledR}, 350 \times 21.1 \mathrm{~mm}$ column; Phenomenex, Torrance, CA, USA). Each post-SEC extract was reduced in volume, added to a solid-phase 2-g silica glass extraction column (Isolute, International Sorbent Technology, Ltd., Hengoed Mid Glamorgan, UK) and eluted with $3.5 \mathrm{~mL}$ hexane (to waste), followed by $6.5 \mathrm{~mL}$ of $60: 40$ hexane/DCM and $8 \mathrm{~mL}$ DCM. The latter two fractions were combined, pooled and then split, with half going for coplanar $\mathrm{PCB}$ analysis. Coplanar PCBs were separated from nonplanar PCBs by elution through a Supleclean ENVI-Carb SPE column (Sigma-Aldrich Co., St. Louis, MO, USA). The column was first eluted with $15 \mathrm{~mL}$ hexane (to waste). The coplanar congeners were obtained by elution with $20 \mathrm{~mL}$ hexane/toluene (99:1) and $20 \mathrm{~mL}$ toluene. The pooled eluent was reduced in volume, spiked with $p$-terphenyl (Ultra Scientific, North Kingstown, RI, USA) as an internal standard, and analyzed by gas chromatography/mass spectrometry (GC/MS) on an Agilent 5975C instrument (Agilent Technologies, Santa Clara, CA, USA), in electron impact mode and selected ion monitoring. A $60 \mathrm{~m}$ DB-5 MS GC column (Agilent, $0.32 \mathrm{~mm}$ ID $\times 0.1 \mu \mathrm{m}$ thickness) was used.

The second half of the silica SPE fraction retained was spiked with decachlorodiphenyl ether (Ultra Scientific) as the internal quantitation standard. Identification and quantitation of noncoplanar PCBs was conducted by GC/MS in the electron ionization mode on a Varian 2200 GC/MS (Agilent Technologies). Organochlorine pesticides and methoxytriclosan were analyzed similarly by GC/MS on a Varian 4D MS. Both analyses used 60-m DB-5 columns $(0.32 \mathrm{~mm}$ ID $\times 0.25 \mu \mathrm{m}$ thickness $)$.

The PBDEs and alt-BFRs were analyzed using this same fraction. PBDEs and alt-BFRs were separated by ultra-performance liquid chromatography (UPLC, Waters Corp., Milford, MA, USA) and analyzed by atmospheric pressure photoionization tandem mass spectrometry (APPI/MS/MS, Q-Trap3200 MS, AB Sciex, Framingham, MA, USA). Further details of the UPLC-APPI/MS analysis can be found in La Guardia et al. (2013).

\subsection{Quality control and assurance}

Instrumental analysis and laboratory QA/QC for method development are described in Chen et al. (2008). The method detection limit (MDL) for organochlorine pesticides and noncoplanar PCB congeners was $0.4 \mu \mathrm{g} / \mathrm{kg}$ ww, coplanar PCBs was $0.04 \mu \mathrm{g} / \mathrm{kg} w \mathrm{w}$, and PBDEs and alt-BFRs was $0.4 \mu \mathrm{g} / \mathrm{kg}$ ww. Data were corrected based on the recovery of surrogate standards in each sample. For quantification of organochlorine pesticides and methoxytriclosan, average recovery of the surrogate standard PCB204 (similar physiochemical properties to the organochlorine pesticides) and ${ }^{13} \mathrm{C}$-methoxytriclosan from the eggs were (mean \pm SD) $85.9 \pm 11.0 \%$. Recoveries of the surrogates for the noncoplanar PCBs (PCB-204) averaged $94.9 \pm 13.7 \%$, coplanar PCBs $97.9 \pm 0.13 \%$, and brominated flame retardants (BDE 166) $98.6 \pm 24.1 \%$. Overall, moisture content (adjusted to fresh weight) in eggs averaged $83.7 \pm 1.37 \%$. 
Due to changes in analytical methodologies and laboratories used between 2000-2001 (Rattner et al., 2004) and 2011-2012, a subset of 11 egg homogenates (three on the Anacostia/middle Potomac Rivers, five from Baltimore Harbor/Patapso Rivers, and three on the Elizabeth River) from 2000-2001 were re-analyzed with current samples. Based on data from our earlier work (Rattner et al., 2004), we selected those samples containing a range (relatively low, intermediate and high) of $p, p^{\prime}$-DDE and total PCB residues. A comparison of the major stable groups of contaminants ( $p, p^{\prime}$-DDE, total PCBs, and sum of PBDE congeners 47, 99, 100, 153 and 154) was conducted and the percent differences between each analysis was calculated (Supplemental Table S1). Individual PCB congener patterns were not evaluated on a temporal perspective due to substantial differences in analytical methodologies. Percent difference of moisture content of these samples in 2000-2001 and 2011-2012 changed by only $1.48 \%$, indicating that sample moisture had not changed appreciably. However, in 2000-2001, moisture correction was determined by mathematically adjusting to the volume of the entire egg (Rattner et al., 2004), while in 2011-2012 we physically adjusted by the addition of distilled water (Heinz et al., 2009).

In 2000-2001, PCBs were analyzed at the Geochemical and Environmental Research Group (GERG) at Texas A\&M using an Aroclor profile-based analysis. Wet samples were mixed with sodium sulfate, spiked with surrogates and extracted with DCM in a Teckmar Tissumizer. Extracts were cleaned up on a silica/alumina column and purified by HPLC to remove interfering lipids. Identification/quantification was by GC in concert with electron capture detection (ECD) using an Aroclor profile-based approach (Rattner et al., 2004). In contrast, VIMS conducted a congener-based analysis using GC/MS in 2011-2012 (Chen et al., 2008). Thus, some differences in results between the two analytical methods were expected. Total PCB concentrations from 11 samples were comparable using the two methodologies, with some 2011-2012 estimates being greater and others being less (average percent difference of $23.7 \pm 20.5 \%$ ) than values reported by GERG in 2000-2001. This seems quite reasonable, as others (Turle et al., 1991) reported that total PCB concentrations from Aroclor-based analyses were on average $46 \%$ greater than congener-based analyses.

The VIMS conducted PBDE analyses of the 2000-2001 egg samples using GC/MS (Rattner et al., 2004) and the re-analysis of a subset of five of these samples using ultra-performance liquid chromatography (UPLC)/MS 10 years later. Of the five samples reanalyzed in 2011-2012, average percent difference between the original samples and their re-analysis was $17.9 \pm 13.4 \%$ (with some 2011-2012 measurements higher and some lower compared to GERG values from 2000-2001). Perhaps most surprisingly, the reanalysis of 11 archived samples for $p, p^{\prime}$-DDE varied by $44.3 \pm 24.5 \%$ (Supplemental Table S1). A GC/ECD method was used by GERG for the original 2000-2001 analyses, whereas a GC/MS method was employed for the re-analysis by VIMS. All surrogate recoveries within the 2011-2012 samples were acceptable (84.9 $\pm 11.0 \%)$. Thus, due to variation between labs, years and sample storage, quantitative comparisons between $p, p^{\prime}$-DDE values from this current study with published values (Rattner et al., 2004) are not justified. Notably, values for $p, p^{\prime}$-DDE in osprey eggs in 2011-2012 were well below the threshold for eggshell thinning ( 9 of 11 were $<1.0 \mu \mathrm{g} / \mathrm{g}$ ww; Wiemeyer et al., 1988).

\subsection{Toxic equivalents for $P C B$ congeners}

The World Health Organization toxic equivalency factors (TEFs) were used to estimate the toxic equivalent (TEQ) for birds (van den Berg et al., 1998). Since 1998, TEFs have changed slightly for mammals, but not for avian species (van den Berg et al., 2006). The TEQ of $A h$-receptor active PCB congeners was calculated by multiplying the congener concentration $(\mathrm{pg} / \mathrm{g} \mathrm{ww}$ ) by the TEF and summing individual values.

\subsection{DNA damage assay}

Whole blood from osprey nestlings was analyzed for the presence of 8-hydroxy-2'-deoxyguanosine (8-OH-dG), a biomarker of oxidative DNA damage, using the DNA/RNA Oxidative Damage EIA Kit (Cayman Chemical, Ann Arbor, MI, USA). This analysis followed the protocol and assay validation described in Rattner et al. (2013). The limit of detection for this assay was $1.03 \mathrm{pg} / \mu \mathrm{g}$ DNA. Plates included blanks and reference samples to account for inter-assay variability. Samples were analyzed in duplicate.

Standard curves were fitted and concentrations determined using a 4-parameter model $\left(\mathrm{R}^{2}>0.998\right.$; MARS Data Analysis Software 2.10 R3, BMG Labtech). Samples collected in 2011 and 2012 were assayed separately. Precision of duplicate determinations (intra-assay variation, coefficient of variation, $\mathrm{CV} \pm \mathrm{SD}$ ) was $3.8 \pm 2.7 \%$ for samples collected in 2011 and $5.1 \pm 3.1 \%$ for samples collected in 2012. Duplicate analyses with a CV greater than $20 \%$ were re-analyzed. Inter-assay variation (CV among assay plates) for reference samples was $9.9 \pm 11.3 \%$. Due to a number of factors (e.g., DNA degradation in samples stored for varying durations, observed variation in assay performance among test kit lots), we were unable to justify statistical comparisons of results between the 2011 and 2012 collections.

\subsection{Statistical analysis}

Simple descriptive statistics were generated for measurement endpoints. Continuously distributed variables (productivity, eggshell thickness, morphometrics, DNA damage and contaminant residues) were tested for normality and homogeneity of variance, and $\log$ transformed as necessary (SAS 9.3, SAS Institute Inc., Cary, NC, USA). Comparisons were made among tributaries using analysis of variance (ANOVA) followed by Tukey's HSD multiple mean comparison test to detect site-specific differences $(\alpha=0.05)$. For those variables that did not meet assumptions for parametric analysis, a generalized Wilcoxon non-parametric test was used followed by a Bonferroni adjustment for comparison of multiple means. A Fisher's Exact test was used to compare overall sitespecific differences in productivity endpoints. For those sampling sites with residues below the MDL in $<50 \%$ of the samples, the potential range of the mean was reported using the Kaplan-Meier method (Helsel, 2005). Any outliers were eliminated from the dataset using a Grubb's test.

Egg, young and nest survival probabilities were calculated using the Mayfield method (Mayfield, 1961; Bart and Robson, 1982). For those variables that were not normally distributed and/or exhibited heterogeneous variance, a generalized Wilcoxon non-parametric test was used. If this was significant, two-sample comparisons were conducted and $p$-values were adjusted using a Bonferroni correction. Results for total PCBs and PBDEs were statistically compared between the 2011-2012 and 2000-2001 from (Rattner et al., 2004) collections using a t-test.

A logistic analysis of covariance was used to examine sitespecific differences in the relationship between egg residues ( $p, p^{\prime}$-DDE, total PCBs, PBDEs and the sum of $p, p^{\prime}$-DDE + total PCBs) and productivity (nest success, egg loss). If no differences were detected, logistic regression was used to evaluate the relation between residues and productivity across sites. 
Table 1

Reproductive success of osprey nesting in Chesapeake Bay Regions of Concern.

\begin{tabular}{|c|c|c|c|c|c|c|c|c|}
\hline \multirow[t]{3}{*}{ Site } & \multirow{2}{*}{\multicolumn{2}{|c|}{$\begin{array}{l}\text { Poplar Island } \\
2011-2012\end{array}$}} & \multirow{2}{*}{\multicolumn{2}{|c|}{$\begin{array}{l}\text { Baltimore Harbor and } \\
\text { Patapsco River } \\
2011\end{array}$}} & \multirow{2}{*}{\multicolumn{2}{|c|}{$\begin{array}{l}\text { Anacostia and middle } \\
\text { Potomac Rivers } \\
2011\end{array}$}} & \multirow{2}{*}{\multicolumn{2}{|c|}{$\begin{array}{l}\text { Elizabeth River } \\
2012\end{array}$}} \\
\hline & & & & & & & & \\
\hline & Number & $\%$ & Number & $\%$ & Number & $\%$ & Number & $\%$ \\
\hline Active nests sampled & 8 & & 7 & & 9 & & 6 & \\
\hline Eggs laid & 24 & & 22 & & 29 & & 18 & \\
\hline Sample egg collected & 8 & & 7 & & 9 & & 6 & \\
\hline Eggs relaid due to predation & 0 & & 0 & & 3 & & 0 & \\
\hline Eggs naturally incubated & 16 & & 15 & & 23 & & 12 & \\
\hline \multicolumn{9}{|l|}{ Fate of eggs } \\
\hline Unknown or predation $^{a}$ & 5 & & 5 & & 9 & & 4 & \\
\hline Storm or wind related & 0 & & 0 & & 0 & & 0 & \\
\hline Crushed/rotten & 0 & & 0 & & 1 & & 0 & \\
\hline Failed to hatch ${ }^{\mathrm{b}}$ & 0 & & 0 & & 2 & & 1 & \\
\hline Hatched & $(11 / 16)$ & $68.8 \%$ & $(10 / 15)$ & $66.7 \%$ & $(11 / 23)$ & $47.8 \%$ & $(7 / 12)$ & $58.3 \%$ \\
\hline Hatchability $^{c}$ & $(11 / 11)$ & $100 \%$ & $(10 / 10)$ & $100 \%$ & $(11 / 14)$ & $78.6 \%$ & $(7 / 8)$ & $87.5 \%$ \\
\hline \multicolumn{9}{|l|}{ Fate of nestlings } \\
\hline Dissappeared & 0 & & 0 & & 1 & & 1 & \\
\hline Storm or wind related & 0 & & 0 & & 0 & & 0 & \\
\hline Found dead & 0 & & 0 & & 0 & & 0 & \\
\hline Fledged $^{c}$ & $(11 / 11)$ & $100 \%$ & $(10 / 10)$ & $100 \%$ & $(10 / 11)$ & $90.9 \%$ & $(6 / 7)$ & $85.7 \%$ \\
\hline Successful pairs (fledged young) & $(6 / 8)$ & $75.0 \%$ & $(5 / 7)$ & $71.4 \%$ & $(5 / 9)$ & $55.5 \%$ & $(4 / 6)$ & $66.7 \%$ \\
\hline Fledlings/active nest & $(11 / 8) 1.38$ & & $(10 / 7) 1.43$ & & $(10 / 9) 1.11$ & & $(6 / 6) 1.00$ & \\
\hline Fledglings/successful nest & $(11 / 6) 1.83$ & & $(10 / 5) 2.00$ & & $(10 / 5) 2.00$ & & $(6 / 4) 1.50$ & \\
\hline \multicolumn{9}{|l|}{ Mayfield method estimates } \\
\hline Egg laying and incubation period & 8 & & 7 & & 9 & & 6 & \\
\hline Daily survival rate \pm standard error & $0.989 \pm 0.008$ & & $0.989 \pm 0.007$ & & $0.987 \pm 0.007$ & & $0.990 \pm 0.007$ & \\
\hline Survival rate to hatching $(\mathrm{A})$ & 0.650 & & 0.650 & & 0.600 & & 0.676 & \\
\hline Nestling period & 6 & & 5 & & 5 & & 4 & \\
\hline Daily survival rate \pm standard error & 1.000 & & 1.000 & & 1.000 & & 1.000 & \\
\hline Survival rate to fledging (B) & 1.000 & & 1.000 & & 1.000 & & 1.000 & \\
\hline Nest success $(\mathrm{A} \times \mathrm{B})$ & 0.650 & & 0.650 & & 0.600 & & 0.676 & \\
\hline $\begin{array}{l}\text { Probability of an egg hatching given } \\
\text { that the nest is successful (C) }\end{array}$ & 0.916 & & 0.909 & & 0.846 & & 0.875 & \\
\hline $\begin{array}{l}\text { Probability of young living to } 53 \mathrm{~d} \\
\text { given that the nest is successful (D) }\end{array}$ & 1.000 & & 1.000 & & 0.909 & & 0.857 & \\
\hline Egg success $(A \times B \times C \times D)$ & 0.595 & & 0.591 & & 0.461 & & 0.507 & \\
\hline Mean clutch size (E) & 3.00 & & 3.14 & & 3.11 & & 3.00 & \\
\hline $\begin{array}{l}\text { Mean number of young surviving } \\
\text { to } 53 \mathrm{~d}(\mathrm{~A} \times \mathrm{B} \times \mathrm{C} \times \mathrm{D} \times \mathrm{E})\end{array}$ & 1.79 & & 1.86 & & 1.43 & & 1.52 & \\
\hline $\begin{array}{l}\text { Mean number of young surviving } \\
\text { to } 53 \mathrm{~d} \text { less sample egg }(\mathrm{A} \times \mathrm{B} \times \mathrm{C} \times\end{array}$ & 1.19 & & 1.26 & & 0.97 & & 1.01 & \\
\hline
\end{tabular}

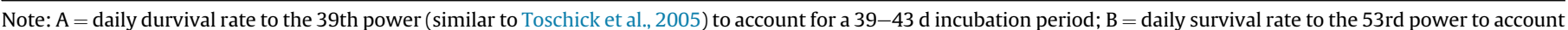

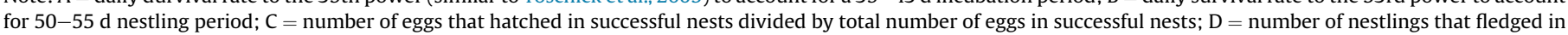
successful nests divided by the total number of nestlings in successful nests; $\mathrm{E}=$ mean clutch size.

a Considered to be lost during the egg stage.

b Eggs in nest $>45$ days or abandoned.

${ }^{c}$ Hatchability = eggs hatched/(eggs laid-eggs that disappeared or sampled before hatching), represents the \% of eggs that remain in the nest through hatch.

\section{Results}

\subsection{Reproduction of ospreys}

In 2011, 36 nests were identified along a 25-km segment on the Anacostia River, from the Frederick Douglass Bridge to Dogue Creek, a tributary of the middle Potomac River. Thirty nests were found along a $20-\mathrm{km}$ stretch from Baltimore Harbor (Curtis Creek) east to the mouth of Patapsco River (Bodkin Point). In 2012, 29 nests were found along a $20-\mathrm{km}$ stretch of the Elizabeth River (including the Lafayette River, West and South branches). No nests were found on the East branch of the River. At Poplar Island (reference site), there were 12 active nests in 2011 and 24 in 2012. Osprey nest density based on total water surface area surveyed was 1 nest/ $1.60 \mathrm{~km}^{2}$ on the Anacostia/middle Potomac Rivers, 1 nest $/ 3.9 \mathrm{~km}^{2}$ in Baltimore Harbor/Patapsco River, and 1 nest $/ 3.57 \mathrm{~km}^{2}$ on Elizabeth River. Poplar Island had the highest density of osprey nests in 2012 , at 1 nest $/ 0.19 \mathrm{~km}^{2}$.

Productivity, the average number of fledglings per active nest, at each location ranged from 1.00 to 1.43 (Table 1 ). There were no site- specific differences in number of eggs laid, egg loss, hatching success, chick loss, and fledging and nest success (Fisher's Exact Test and generalized Wilcoxon non-parametric test, $p>0.35$ ). On average, 3.09 eggs were laid/nest, $39.6 \%$ of eggs laid were lost, $91.5 \%$ of the eggs retained in nests hatched (hatchability), and $94.2 \%$ of the hatchlings survived to fledge. While not statistically significant, it is noteworthy that the lowest percentages of successful pairs and fledglings produced per active nest were on the Anacostia/middle Potomac (55.5\% successful pairs, 1.11 fledglings/active nest) and the Elizabeth Rivers $(66.7 \%, 1.00)$. Once hatched, most chicks survived to fledge with the exception of the disappearance of one nestling on the Potomac River, and one nestling on the Elizabeth River.

\subsection{Eggshell thickness and morphological endpoints}

On Poplar Island, no significant differences (t-test, $p>0.8$ ) were found in osprey eggshell thickness between 2011 and 2012; accordingly, samples from both years were combined for this reference site. There was an overall difference among sites (ANOVA, $p=0.05$ ). Using Tukey's HSD mean separation test, 
Table 2

Concentrations $(\mu \mathrm{g} / \mathrm{g} w \mathrm{w})$ of organochlorine pesticides and metabolites from Chesapeake Bay Regions of Concern and Poplar Island reference site. ${ }^{\mathrm{a}}$

\begin{tabular}{|c|c|c|c|c|}
\hline \multirow[t]{2}{*}{ Contaminant } & $\begin{array}{l}\text { Poplar Island } \\
2011-2012(\mathrm{n}=8)\end{array}$ & $\begin{array}{l}\text { Baltimore Harbor and } \\
\text { Patapsco River } 2011(\mathrm{n}=7)\end{array}$ & $\begin{array}{l}\text { Anacostia and middle } \\
\text { Potomac Rivers } 2011(\mathrm{n}=9)\end{array}$ & $\begin{array}{l}\text { Elizabeth River } \\
2012(\mathrm{n}=6)\end{array}$ \\
\hline & $\begin{array}{l}\text { Geometric mean }{ }^{\mathrm{b}} \\
\text { extremes } \\
n \text { detected }\end{array}$ & $\begin{array}{l}\text { Geometric mean }{ }^{\mathrm{b}} \\
\text { extremes } \\
n \text { detected }\end{array}$ & $\begin{array}{l}\text { Geometric mean }{ }^{\mathrm{b}} \\
\text { extremes } \\
n \text { detected }\end{array}$ & $\begin{array}{l}\text { Geometric mean }^{\mathrm{b}} \\
\text { extremes } \\
n \text { detected }\end{array}$ \\
\hline \multirow[t]{3}{*}{$p, p^{\prime}-\mathrm{DDE}$} & $0.152^{\mathrm{B}}$ & $0.553^{\mathrm{A}}$ & $0.725^{\mathrm{A}}$ & $0.488^{\mathrm{A}}$ \\
\hline & $0.090-0.206$ & $0.286-1.831$ & $0.477-1.018$ & $0.240-0.873$ \\
\hline & 8 & 7 & 9 & 6 \\
\hline \multirow[t]{3}{*}{$p, p^{\prime}-\mathrm{DDD}$} & $0.009^{\mathrm{B}}$ & $0.046^{\mathrm{A}}$ & $0.042^{\mathrm{A}}$ & $0.048^{\mathrm{A}}$ \\
\hline & $0.006-0.017$ & $0.016-0.190$ & $0.022-0.072$ & $0.012-0.117$ \\
\hline & 8 & 7 & 9 & 6 \\
\hline \multirow{3}{*}{ Dieldrin } & - & $0.020-0.021$ & 0.02 & - \\
\hline & $<\mathrm{MDL}$ & $<$ MDL-0.057 & $0.008-0.035$ & $<\mathrm{MDL}$ \\
\hline & 0 & 5 & 9 & 0 \\
\hline \multirow[t]{3}{*}{ Heptachlor epoxide } & - & $0.022^{\mathrm{B}}$ & $0.047^{\mathrm{A}}$ & - \\
\hline & $<$ MDL-0.006 & $0.015-0.05$ & $0.028-0.10$ & $<$ MDL-0.004 \\
\hline & 2 & 7 & 9 & 1 \\
\hline \multirow[t]{3}{*}{$\alpha$-Chlordane (cis) } & - & $0.013^{\mathrm{A}}$ & $0.024^{\mathrm{A}}$ & $0.0049-0.0050^{\mathrm{B}}$ \\
\hline & $<$ MDL-0.002 & $0.006-0.032$ & $0.015-0.04$ & $<$ MDL-0.010 \\
\hline & 1 & 7 & 9 & 5 \\
\hline \multirow[t]{3}{*}{$\gamma$-Chlordane (trans) } & - & $0.002-0.003$ & $0.00280-0.00284$ & - \\
\hline & $<\mathrm{MDL}$ & $<$ MDL-0.010 & $<$ MDL-0.005 & $<\mathrm{MDL}$ \\
\hline & 0 & 4 & 8 & 0 \\
\hline \multirow[t]{3}{*}{ cis-Nonachlor } & $0.004^{\mathrm{C}}$ & $0.030^{\mathrm{A}, \mathrm{B}}$ & $0.045^{\mathrm{A}}$ & $0.0159-0.0160^{\mathrm{B}, \mathrm{C}}$ \\
\hline & $0.002-0.005$ & $0.011-0.06$ & $0.028-0.058$ & $<$ MDL-0.035 \\
\hline & 8 & 7 & 9 & 5 \\
\hline \multirow[t]{3}{*}{ trans-Nonachlor } & $0.00243-0.00248^{C}$ & $0.015^{\mathrm{A}, \mathrm{B}}$ & $0.025^{\mathrm{A}}$ & $0.00670-0.00676^{\mathrm{B}, \mathrm{C}}$ \\
\hline & $<$ MDL-0.004 & $0.007-0.031$ & $0.018-0.037$ & $<$ MDL-0.012 \\
\hline & 7 & 7 & 9 & 5 \\
\hline \multirow[t]{3}{*}{ Oxychlordane } & - & $0.0110-0.0111^{\mathrm{B}}$ & $0.025^{\mathrm{A}}$ & - \\
\hline & $<\mathrm{MDL}$ & $<$ MDL-0.026 & $0.016-0.051$ & $<$ MDL-0.009 \\
\hline & 0 & 5 & 9 & 1 \\
\hline \multirow[t]{3}{*}{ Mirex } & $0.0017-0.0018^{\mathrm{B}}$ & $0.00368-0.00374^{\mathrm{A}, \mathrm{B}}$ & $0.004^{\mathrm{A}}$ & $0.0023-0.0024^{\mathrm{A}, \mathrm{B}}$ \\
\hline & $<$ MDL-0.003 & $<$ MDL-0.007 & $0.003-0.005$ & $<$ MDL-0.004 \\
\hline & 6 & 6 & 9 & 5 \\
\hline
\end{tabular}

a - No mean calculated, as contaminant was detected in fewer than half the samples; MDL, method detection limit; extremes are defined as the minimum and maximum

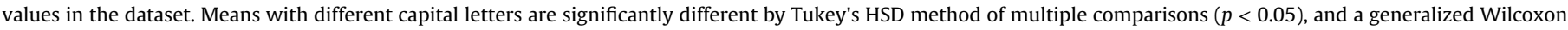
non-parametric test followed by pairwise comparisons using a Bonferroni correction.

${ }^{b}$ If non-detects were present in less than half of the samples, the Kaplan-Meier method was used to estimate the extremes of the mean.

eggshell thickness on the Anacostia/middle Potomac Rivers $(0.481 \pm 0.049 \mathrm{~mm})$ was significantly lower than for Poplar Island $(0.549 \pm 0.057 \mathrm{~mm})(p=0.04)$. While eggshell thickness was numerically lowest on the Anacostia/middle Potomac Rivers compared to the other sites (Baltimore Harbor $0.504 \pm 0.040 \mathrm{~mm}$ and Elizabeth River $0.529 \pm 0.044 \mathrm{~mm}$ ), this trend was not significant $(p>0.48)$. Of the egg that failed to hatch on the Potomac, there was no evidence of eggshell thinning $(0.503 \mathrm{~mm})$.

All nestlings examined were in good body condition. One chick on the Elizabeth River had a plastic bag around its neck, but otherwise appeared to be fine. Osprey nestling body weight (body weight minus estimated weight of food in crop; Schaadt and Bird, 1993) was compared among sites. Several of the nestlings on the Elizabeth River had mites and there were instances of feather plucking indicative of sibling competition for food. There were no differences in body weight between sampling years on Poplar Island (t-test, $p>0.6$ ); therefore, measurements were combined. There were no differences in osprey nestling body weight among the four sites ( $p=0.11$, ANOVA; Poplar Island 2011-2012,1603 $\pm 159 \mathrm{~g}$; Anacostia/ middle Potomac Rivers $1480 \pm 144 \mathrm{~g}$; Baltimore Harbor/Patapsco Rivers $1551 \pm 140 \mathrm{~g}$; Elizabeth River $1365 \pm 138 \mathrm{~g}$ ). There were no differences in culmen length among sites ( $p=0.3$, ANOVA) and values ranged by $5.2 \mathrm{~mm}(26.9-32.1 \mathrm{~mm})$.

\subsection{Organochlorine pesticides and metabolites}

Twenty-five out of 44 organochlorine pesticides and metabolites were detected in eggs at concentrations exceeding the MDL.
The Anacostia/middle Potomac Rivers and Baltimore Harbor/ Patapsco River sites had greatest pesticide and metabolite residues, some exceeding Poplar Island values (2.2-11.5 times) by more than an order of magnitude (Table 2). The Anacostia/middle Potomac also had the highest frequency of detects and measureable concentrations were found in all eggs sampled at this site with the exception of trans-chlordane (present in 8 of 9 eggs). Of this dataset, only one egg from Baltimore Harbor had p,p'-DDE concentrations $(1.8 \mu \mathrm{g} / \mathrm{g} \mathrm{ww})$ that fell within the 95\% confidence interval $(1.2-3.0 \mu \mathrm{g} / \mathrm{g}$ ww) associated with $10 \%$ shell thinning in osprey eggs $(2.0 \mu \mathrm{g} / \mathrm{g}$ ww; Wiemeyer et al., 1988). There was no relation between $p, p$ '-DDE concentration and eggshell thickness $(r=-0.14$, $p=0.459, \mathrm{n}=30$ ).

\subsection{Polychlorinated biphenyls}

Total PCB concentrations were up to five times greater in Baltimore Harbor and the Anacostia/middle Potomac Rivers $(p<0.0001)$ than at the reference site (Table 3$)$. Some of the greatest values were detected in eggs collected in Baltimore Harbor, ranging up to $35.0 \mu \mathrm{g} / \mathrm{g}$ ww. Of the most potent $A h$-receptor active PCB congeners $(77,81,126,169)$, residues of PCB 77 and 126 did not differ from the reference site. However, residues of PCB congeners 81 and 169 in eggs were greater on the Elizabeth River compared to the Anacostia/middle Potomac Rivers and Baltimore Harbor $(p<0.01)$, but were not detected at Poplar Island. In terms of $A h-$ receptor active PCB congeners, Baltimore Harbor and the Anacostia/ middle Potomac Rivers had greater TEQs (16.3 and $12.8 \mathrm{pg} / \mathrm{g}$ 
Table 3

Concentrations ( $\mu \mathrm{g} / \mathrm{g}$ ww) of polychlorinated biphenyls and congeners from Chesapeake Bay Regions of Concern and Poplar Island reference site. ${ }^{\mathrm{a}}$

\begin{tabular}{|c|c|c|c|c|}
\hline \multirow[t]{2}{*}{ Contaminant } & $\begin{array}{l}\text { Poplar Island } \\
2011-2012(\mathrm{n}=8)\end{array}$ & $\begin{array}{l}\text { Baltimore Harbor and } \\
\text { Patapsco River } 2011(n=7)\end{array}$ & $\begin{array}{l}\text { Anacostia and middle } \\
\text { Potomac Rivers } 2011(n=9)\end{array}$ & $\begin{array}{l}\text { Elizabeth River } \\
2012(\mathrm{n}=6)\end{array}$ \\
\hline & $\begin{array}{l}\text { Geometric mean }{ }^{\mathrm{b}} \\
\text { extremes } \\
n \text { detected }\end{array}$ & $\begin{array}{l}\text { Geometric mean } \\
\text { extremes } \\
n \text { detected }\end{array}$ & $\begin{array}{l}\text { Geometric mean }^{\mathrm{b}} \\
\text { extremes } \\
n \text { detected }\end{array}$ & $\begin{array}{l}\text { Geometric mean }^{\mathrm{b}} \\
\text { extremes } \\
n \text { detected }\end{array}$ \\
\hline \multirow[t]{3}{*}{ Total PCBs $(\mu \mathrm{g} / \mathrm{g})$} & $1.50^{C}$ & $7.77^{\mathrm{A}}$ & $5.57^{\mathrm{A}, \mathrm{B}}$ & $2.92^{\mathrm{B}, \mathrm{C}}$ \\
\hline & $1.00-1.93$ & $2.94-35.0$ & $3.88-6.53$ & $0.56-6.85$ \\
\hline & 8 & 7 & 9 & 6 \\
\hline \multirow[t]{3}{*}{ Congener 77 (pg/g) } & $59.6^{\mathrm{A}, \mathrm{B}}$ & $73.8^{\mathrm{A}, \mathrm{B}}$ & $41.0-45.4^{\mathrm{B}}$ & $140^{\mathrm{A}}$ \\
\hline & $17.0-160$ & $48.0-129$ & $<$ MDL-61.0 & $70.0-510$ \\
\hline & 8 & 7 & 8 & 6 \\
\hline \multirow[t]{3}{*}{ Congener 81 (pg/g) } & - & $21.9^{\mathrm{B}}$ & $11.2-11.28^{\mathrm{B}}$ & $115-128^{\mathrm{A}}$ \\
\hline & $<\mathrm{MDL}$ & $15.0-35.0$ & $<$ MDL-29.0 & $<$ MDL-380 \\
\hline & 0 & 7 & 5 & 4 \\
\hline \multirow[t]{3}{*}{ Congener 126 (pg/g) } & 139 & 243 & $206-210$ & $603-610$ \\
\hline & $61-270$ & $107-647$ & $<$ MDL-290 & $<$ MDL-1080 \\
\hline & 8 & 7 & 8 & 5 \\
\hline \multirow[t]{3}{*}{ Congener 169 (pg/g) } & - & $39.3-45.0^{\mathrm{B}}$ & $24.1-33.0^{\mathrm{A}, \mathrm{B}}$ & $75.0-88.3^{\mathrm{A}}$ \\
\hline & $<\mathrm{MDL}$ & $<$ MDL-91.0 & $<$ MDL-36.0 & $<$ MDL-140 \\
\hline & 0 & 6 & 8 & 4 \\
\hline \multirow[t]{3}{*}{ Congener 105 (ng/g) } & $8.54-8.60^{\mathrm{B}}$ & $45.0^{\mathrm{A}}$ & $36.7^{\mathrm{A}}$ & $25.3^{A, B}$ \\
\hline & $<$ MDL-16.3 & $11.9-199$ & $23.8-66.1$ & $6.79-69.0$ \\
\hline & 7 & 7 & 9 & 6 \\
\hline \multirow[t]{3}{*}{ Congener 118 (ng/g) } & $59.5^{\mathrm{B}}$ & $363^{A}$ & $277^{\mathrm{A}}$ & $107^{\mathrm{B}}$ \\
\hline & $32.3-79.2$ & $138-1801$ & $103-415$ & $21.9-282$ \\
\hline & 8 & 7 & 9 & 6 \\
\hline \multirow[t]{3}{*}{ Congener 128 (ng/g) } & $21.1^{\mathrm{B}}$ & $141^{\mathrm{A}}$ & $99.1^{\mathrm{A}}$ & $27.7^{\mathrm{B}}$ \\
\hline & $9.28-32.0$ & $53.9-514$ & $39.0-169$ & $7.20-80.2$ \\
\hline & 8 & 7 & 9 & 6 \\
\hline \multirow[t]{3}{*}{ Congener 138/158 (ng/g) } & $158^{\mathrm{B}}$ & $638^{\mathrm{A}}$ & $538^{\mathrm{A}}$ & $286^{\mathrm{A}, \mathrm{B}}$ \\
\hline & $100-246$ & $257-2091$ & $330-975$ & $68.1-546$ \\
\hline & 8 & 7 & 9 & 6 \\
\hline \multirow[t]{3}{*}{ Congener 156 (ng/g) } & $7.97^{\mathrm{B}}$ & $76.4^{\mathrm{A}}$ & $61.2^{\mathrm{A}}$ & $11.7^{\mathrm{B}}$ \\
\hline & $3.28-14.8$ & $26.9-290$ & $29.7-84.5$ & $2.62-25.3$ \\
\hline & 8 & 7 & 9 & 6 \\
\hline \multirow[t]{3}{*}{ Congener 189 (ng/g) } & $1.42-1.52^{\mathrm{B}}$ & $14.3^{\mathrm{A}}$ & $9.16-9.21^{\mathrm{A}}$ & $2.76^{\mathrm{A}, \mathrm{B}}$ \\
\hline & $<\mathrm{MDL}-2.51$ & $4.21-62.3$ & $<$ MDL-11.8 & $0.78-7.33$ \\
\hline & 6 & 7 & 8 & 6 \\
\hline \multirow[t]{3}{*}{ Congener $170 / 190(\mathrm{ng} / \mathrm{g})$} & $52.1^{\mathrm{B}}$ & $373^{\mathrm{A}}$ & $307^{\mathrm{A}}$ & $95.1^{\mathrm{B}}$ \\
\hline & $29.1-86.6$ & $108-1619$ & $212-412$ & $24.0-239$ \\
\hline & 8 & 7 & 9 & 6 \\
\hline \multirow{3}{*}{ Toxic equivalents (pg/g) } & $2.30^{\mathrm{B}}$ & $16.3^{\mathrm{A}}$ & $12.8^{\mathrm{A}}$ & $4.91^{\mathrm{B}}$ \\
\hline & $1.18-3.23$ & $5.31-67.7$ & $6.66-19.4$ & $1.17-11.6$ \\
\hline & 8 & 7 & 9 & 6 \\
\hline
\end{tabular}

a - No mean calculated, as contaminant was detected in fewer than half the samples; MDL, method detection limit; extremes are defined as the minimum and maximum

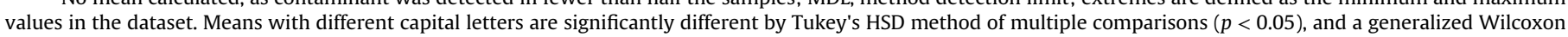
non-parametric test followed by pairwise comparisons using a Bonferroni correction.

$\mathrm{b}$ If non-detects were present in less than half of the samples, the Kaplan-Meier method was used to estimate the extremes of the mean.

respectively; $p<0.04)$ than the Elizabeth River and the reference site (4.91 and $2.30 \mathrm{pg} / \mathrm{g} \mathrm{ww})$.

\subsection{Polybrominated diphenyl ether flame retardants}

Congeners 47, 85, 99, 100, 153, 154, 183, 206 and 209 were detected in osprey eggs collected from one or more sites (Table 4). Penta-BDE congener 85, hepta-183, nona-206 and 209 were detected less frequently than other congeners in samples. Congeners 28 and 66 were not detected in any of the samples. Osprey eggs from Poplar Island had the lowest PBDE congener residues; concentrations did not differ between 2011 and $2012(p>0.05)$ and were combined. There were significant site differences for both total PBDEs and BDE 47 ( $p<0.0001$, ANOVA). Specifically, total PBDEs were more than three times greater on the Anacostia/middle Potomac and Baltimore Harbor/Patapsco Rivers compared to the Poplar Island reference site $(p<0.0001)$. This same site pattern and magnitude of difference was also apparent for BDE congener 47 $(p<0.0001)$. The Anacostia/middle Potomac Rivers also had higher concentrations of PBDE congeners 99, 100 and 154 compared to
Poplar Island and the Elizabeth River $(p<0.01)$. An egg collected near Blue Plains Wastewater Treatment Plant (WWTP) contained the greatest total PBDE levels ( $802 \mathrm{ng} / \mathrm{g}$ ww) found in this study. In 2000-2001, PBDE 206 and 209 were not studied. We re-analyzed 11 archived sample homogenates from 2000-2001, and BDE 209 was detected in 3 of 11 samples (range: $0.66-3.88 \mathrm{ng} / \mathrm{g} \mathrm{ww}$; $1 /$ each ROC).

\subsection{Other brominated flame retardants and methoxytriclosan}

Five additional BFRs were quantified in osprey eggs (Table 4). Alpha-HBCD was most frequently detected (26 of 30 eggs), but tended to be at much lower concentrations than the lower brominated BDE congeners. While BTBPE, TBB and TBPH were most frequently detected in samples from Baltimore Harbor/Patapsco River, the maximum detected concentration for each of these altBFRs was found in samples from the Anacostia/middle Potomac Rivers. Methoxytriclosan, a moderately bioaccumulative degradate of the antibacterial agent triclosan, was detected in all 9 samples from the Anacostia/middle Potomac Rivers (1.29-7.40 ng/g ww) 
Table 4

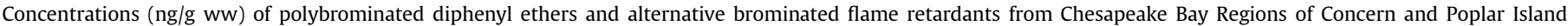
reference site.

\begin{tabular}{|c|c|c|c|c|}
\hline \multirow[t]{2}{*}{ Contaminant } & $\begin{array}{l}\text { Poplar Island } \\
2011-2012(\mathrm{n}=8)\end{array}$ & $\begin{array}{l}\text { Baltimore Harbor and } \\
\text { Patapsco River } 2011(n=7)\end{array}$ & $\begin{array}{l}\text { Anacostia and middle } \\
\text { Potomac Rivers } 2011(\mathrm{n}=9)\end{array}$ & $\begin{array}{l}\text { Elizabeth River } 2012 \\
(\mathrm{n}=6)\end{array}$ \\
\hline & $\begin{array}{l}\text { Geometric mean }{ }^{\mathrm{b}} \\
\text { extremes } \\
n \text { detected }\end{array}$ & $\begin{array}{l}\text { Geometric mean }^{\mathrm{b}} \\
\text { extremes } \\
n \text { detected }\end{array}$ & $\begin{array}{l}\text { Geometric mean }^{\mathrm{b}} \\
\text { extremes } \\
n \text { detected }\end{array}$ & $\begin{array}{l}\text { Geometric mean }^{\mathrm{b}} \\
\text { extremes } \\
n \text { detected }\end{array}$ \\
\hline \multirow[t]{3}{*}{ Total PBDEs } & $61.6^{C}$ & $198^{\mathrm{B}}$ & $452^{\mathrm{A}}$ & $90.7^{\mathrm{C}}$ \\
\hline & $52.3-80.9$ & $106-310$ & $313-802$ & $71.3-141$ \\
\hline & 8 & 7 & 9 & 6 \\
\hline \multirow[t]{3}{*}{ BDE congener 47} & $39.9^{C}$ & $138^{\mathrm{B}}$ & $331^{\mathrm{A}}$ & $46.9^{C}$ \\
\hline & $32.4-48.2$ & $72.4-212$ & $231-648$ & $21.9-90.2$ \\
\hline & 8 & 7 & 9 & 6 \\
\hline \multirow[t]{3}{*}{ BDE congener 85} & - & - & - & - \\
\hline & $<$ MDL-0.76 & $<\mathrm{MDL}$ & $<\mathrm{MDL}$ & $<$ MDL-1.22 \\
\hline & 1 & 0 & 0 & 1 \\
\hline \multirow[t]{3}{*}{ BDE congener 99} & $1.52^{C}$ & $13.2^{\mathrm{A}, \mathrm{B}}$ & $29.7^{\mathrm{A}}$ & $9.39^{\mathrm{B}}$ \\
\hline & $0.17-4.94$ & $7.31-30.6$ & $19.8-49.1$ & $5.68-16.2$ \\
\hline & 8 & 7 & 9 & 6 \\
\hline \multirow[t]{3}{*}{ BDE congener 100} & $8.64^{\mathrm{C}}$ & $17.5^{\mathrm{B}}$ & $54.3^{\mathrm{A}}$ & $14.1^{\mathrm{B}}$ \\
\hline & $4.79-13.5$ & $10.1-23.6$ & $44.1-81.8$ & $9.34-21.2$ \\
\hline & 8 & 7 & 9 & 6 \\
\hline \multirow[t]{3}{*}{ BDE congener 153} & $2.84^{\mathrm{B}}$ & $11.4^{\mathrm{A}}$ & $15.4-15.5^{\mathrm{A}}$ & $4.82^{\mathrm{A}, \mathrm{B}}$ \\
\hline & $2.00-4.42$ & $4.87-25.5$ & $<$ MDL-26.6 & $2.32-7.16$ \\
\hline & 8 & 7 & 8 & 6 \\
\hline \multirow[t]{3}{*}{ BDE congener 154} & $8.18^{\mathrm{B}}$ & $10.5^{\mathrm{A}, \mathrm{B}}$ & $16.4^{\mathrm{A}}$ & $6.62-6.68^{\mathrm{B}}$ \\
\hline & $5.01-11.7$ & $6.47-18.9$ & $11.5-21.1$ & $<$ MDL-9.44 \\
\hline & 8 & 7 & 9 & 5 \\
\hline \multirow[t]{3}{*}{ BDE congener 183} & - & $3.39^{\mathrm{A}}$ & $1.31-1.36^{\mathrm{B}}$ & - \\
\hline & $<\mathrm{MDL}$ & $1.11-8.89$ & $<$ MDL-2.64 & $<\mathrm{MDL}$ \\
\hline & 0 & 7 & 9 & 0 \\
\hline \multirow[t]{3}{*}{ BDE congener 206} & - & - & - & - \\
\hline & $<\mathrm{MDL}$ & $<$ MDL-1.88 & $<\mathrm{MDL}$ & $<$ MDL-2.16 \\
\hline & 0 & 1 & 0 & 1 \\
\hline \multirow[t]{3}{*}{ BDE congner 209} & - & - & - & $13.2-13.3$ \\
\hline & $<$ MDL-1.56 & $<$ MDL-11.4 & $<$ MDL-1.03 & $<$ MDL-75.5 \\
\hline & 2 & 1 & 1 & 3 \\
\hline \multirow[t]{3}{*}{$\alpha-H B C D$} & 1.01 & 1.27 & $1.57-1.60$ & $0.84-0.98$ \\
\hline & $0.36-2.14$ & $0.67-3.72$ & $<$ MDL-3.03 & $<$ MDL-1.36 \\
\hline & 8 & 7 & 7 & 4 \\
\hline \multirow[t]{3}{*}{ ВТВРЕ } & - & $1.56-1.62$ & - & - \\
\hline & $<$ MDL-4.77 & $<$ MDL-3.45 & $<$ MDL-28.9 & $<\mathrm{MDL}$ \\
\hline & 1 & 5 & 4 & 0 \\
\hline \multirow[t]{3}{*}{ DBDPE } & - & - & - & - \\
\hline & $<\mathrm{MDL}$ & $<\mathrm{MDL}$ & $<$ MDL-0.89 & $<\mathrm{MDL}$ \\
\hline & 0 & 0 & 1 & 0 \\
\hline \multirow[t]{3}{*}{ TBB } & - & $1.95-2.01$ & - & - \\
\hline & $<$ MDL-6.42 & $<$ MDL-5.17 & <MDL-30.3 & $<$ MDL-1.58 \\
\hline & 1 & 5 & 1 & 2 \\
\hline \multirow[t]{3}{*}{ ТВРН } & - & $0.30-0.39$ & - & - \\
\hline & $<$ MDL-0.66 & $<$ MDL-0.80 & $<$ MDL-7.37 & $<$ MDL-0.50 \\
\hline & 2 & 4 & 3 & 1 \\
\hline
\end{tabular}

a - No mean calculated, as contaminant was detected in fewer than half the samples; MDL method detection limit; extremes are defined as the minimum and maximum

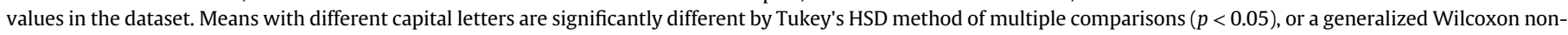
parametric test followed by pairwise comparisons using a Bonferroni correction.

${ }^{b}$ If non-detects were present in less than half of the samples, the Kaplan-Meier method was used to estimate the extremes of the mean.

and in one sample from Baltimore Harbor (5.55 ng/g ww). This compound may serve as a useful marker of domestic wastewater.

The eleven historical egg homogenates were re-analyzed for these five alt-BFRs and methoxytriclosan. Alpha-HBCD was detected in 10 of 11 of the archived 2000-2001 samples with no apparent site-specific differences in concentration (Baltimore Harbor/Patapsco River, $\mathrm{n}=5$ range: $0.53-1.27 \mathrm{ng} / \mathrm{g}$ ww; Elizabeth River, $\mathrm{n}=3$ range: < MDL-1.08 ng/g ww; Anacostia/middle Potomac Rivers, $\mathrm{n}=3$, range: $0.64-1.36 \mathrm{ng} / \mathrm{g} \mathrm{ww})$. Of the remaining four alt-BFRs, BTBPE, DBDPE, TBB and TBPH were consistently detected in two historical samples from Curtis Bay and Shallow Creek off of the Patapsco River (0.30-6.74 ng/g ww). However, methoxytriclosan was only detected in one sample collected in 2000 on the Potomac River (4.89 ng/g ww).

\subsection{Relation between contaminants and osprey productivity}

Analysis of covariance revealed that there were no site-specific associations between $p, p^{\prime}$-DDE and total PBDEs $(p=0.20)$, or between total PCBs and PBDEs $(p=0.07)$. However, there was a significant relation between $p, p^{\prime}$-DDE and PCB residues across sites $(p=0.01)$, with the greatest correlation on the Anacostia/middle Potomac Rivers ( $\mathrm{r}=0.77, \mathrm{n}=9$ ). When data for $p, p^{\prime}$-DDE, total PCBs and total PBDEs were combined across sites $(n=30)$, there was a significant correlation between $p, p^{\prime}$-DDE and total PCBs $(r=0.84$, $p<0.001)$ and $p, p^{\prime}$-DDE and total PBDEs $(r=0.62, p=0.0003)$, and a marginal relation between total PCBs and total PBDEs $(r=0.32$, $p=0.08$ ). There were no associations (site-specific or combined sites) between egg loss or nest success and the concentrations of 


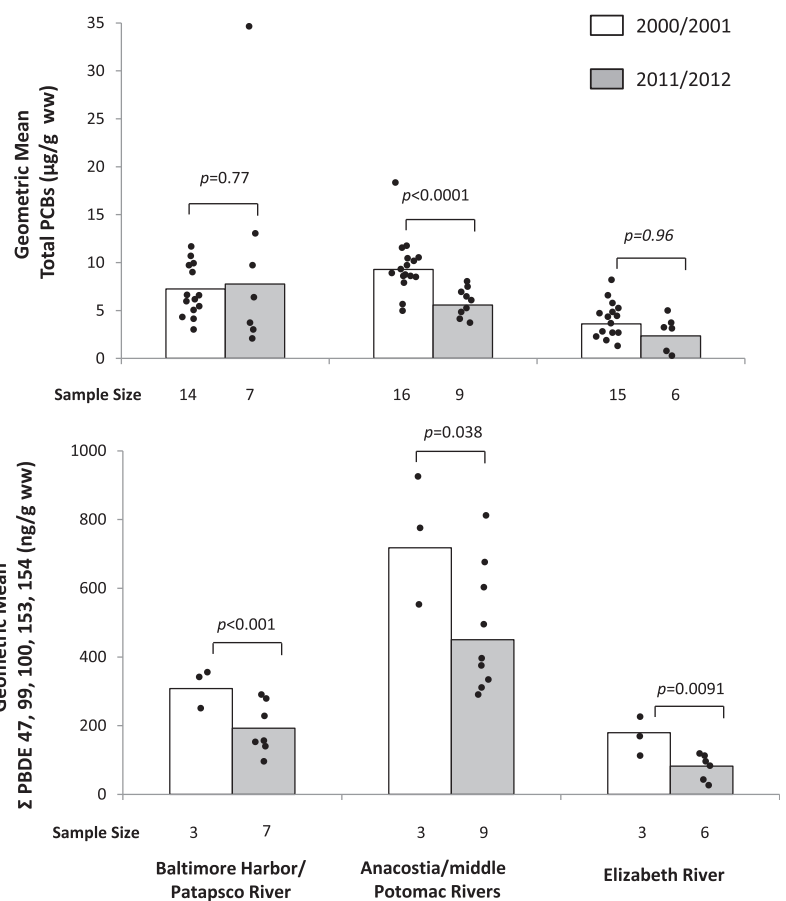

Fig. 2. Temporal comparison of contaminants from Chesapeake Bay Regions of Concern in 2000-2001 (adapted from Rattner et al., 2004) and 2011-2012. Geometric means and individual data points are presented $(\bullet)$. At each site historical and current datasets were compared by a t-test.

$p, p^{\prime}$-DDE, PCBs, PBDEs or the sum of $p, p^{\prime}-\mathrm{DDE}+\mathrm{PCBs}(p>0.09)$.

\subsection{Temporal comparisons}

Concentrations of $p, p^{\prime}$-DDE, total PCBs and PBDE congeners 47, $99,100,153,154$ in eggs collected in 2011-2012 were compared to results from 2000-2001 (Rattner et al., 2004, Fig. 2). Total PCB concentrations remained high in Baltimore Harbor/Patapsco River between decades $(p=0.45)$, but decreased on the Anacostia/middle Potomac Rivers $(9.28 \mu \mathrm{g} / \mathrm{g}$ in $2000-2001$ versus $5.57 \mu \mathrm{g} / \mathrm{g}$ ww in 2011-2012, $p<0.0001$ ). Concentrations of PCBs remained unchanged on the Elizabeth River 10 years later $(p=0.96)$. For

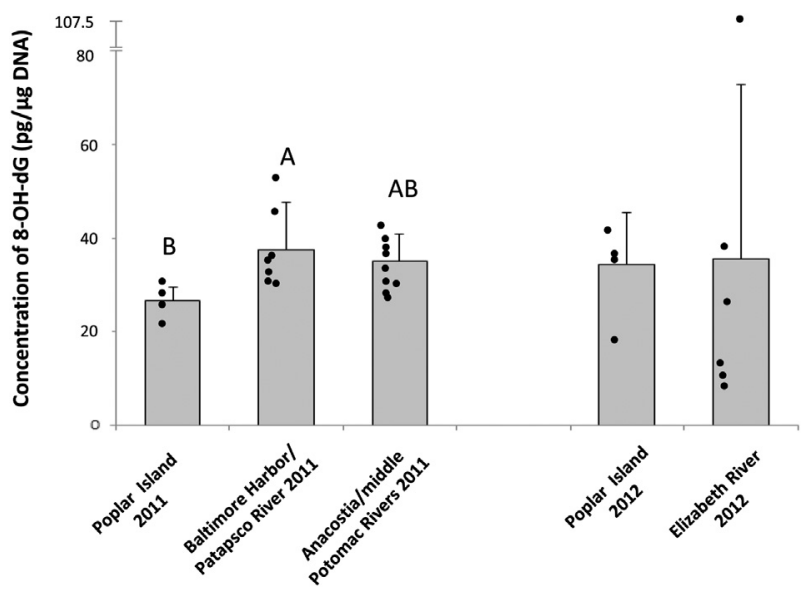

Fig. 3. Concentrations of 8-hydroxy-2'-deoxyguanosine (8-OH-dG) in osprey nestling whole blood samples. Means, standard deviations and individual data points are presented $(\bullet)$. Capital letters indicate a statistically significant difference $(p<0.05)$ using Tukey's HSD test. equitable comparison of total PBDE concentrations, the sum of congeners 47, 99, 100, 153 and 154 were examined between decades. The sum of these congeners across all ROCs declined over time ( $p<0.04$, Fig. 2 ). A qualitative comparison of $p, p^{\prime}$-DDE levels between decades suggests that concentrations were low across all sites, and much lower than historic values (Wiemeyer et al., 1988; Rattner et al., 2004).

\subsection{DNA damage}

In 2011, Baltimore Harbor/Patapsco River had significantly greater concentrations of $8-\mathrm{OH}-\mathrm{dG}(36.4 \mathrm{pg} / \mu \mathrm{g}$ DNA) compared to Poplar Island (26.6 pg/ $\mu$ g DNA, $p=0.04$ ) (Fig. 3), but not the Anacostia/middle Potomac Rivers (35.1 pg/ $\mu$ g DNA, $p=0.9$ ). In 2012, the concentration of $8-\mathrm{OH}-\mathrm{dG}$ in one sample collected from the Elizabeth River (entrance to the Lafayette River) was several times

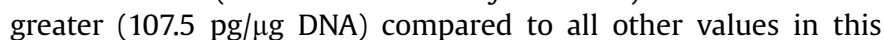
study. While Grubb's test identified this measurement as an outlier, there is no rationale for excluding this value from our statistical analysis. In 2012, there was no significant difference between the

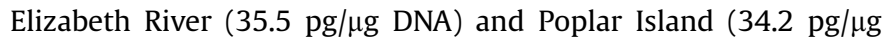
DNA; $p>0.15$ ) with or without exclusion of the outlier.

\section{Discussion}

\subsection{Osprey productivity in Regions of Concern}

Use of the insecticide DDT, and specifically its metabolite $p, p^{\prime}$ DDE, resulted in eggshell thinning and population declines of ospreys (Wiemeyer et al., 1988) and other species of piscivorous birds (Blus, 2011). In the 1970s, the Chesapeake Bay osprey population was estimated at 1450 pairs, with some population segments producing well-below normal rates (Henny et al., 1974). Following restrictions in the use of DDT and other chlorinated pesticides, the Chesapeake osprey population more than doubled by 1995-1996 (Watts et al., 2004).

To determine the recruitment rate needed to maintain a stable osprey population, information is needed on nest site competition, nest availability and age of breeding; thus, it is challenging to identify which productivity rate is best for Chesapeake Bay ROCs (Watts and Paxton, 2007). Historically, it was estimated that 0.8-1.15 fledglings/active nest are required to maintain a stable population (Spitzer, 1980; Spitzer et al., 1983; Poole, 1989), although these estimates have likely changed. While contemporary survivorship data are available for ospreys in Chesapeake Bay (Bryan Watts, unpublished data), a model has yet to be developed to predict the reproductive rate necessary to maintain a stable population. Historical recruitment rates on the southern Potomac in 1970 were 0.55 fledglings/active nest (Wiemeyer, 1971) and in 2000 the reproductive rate was 0.88 on Anacostia/middle Potomac Rivers (Rattner et al., 2004). By 2011, the reproductive rate had further increased to 1.11 fledglings/active nest on the Anacostia/ middle Potomac Rivers, an increase of 0.56 fledglings/active nest over the 1970s. Based on historical estimates (Spitzer, 1980; Spitzer et al., 1983; Poole, 1989), since 2000, productivity in Baltimore Harbor appears to be adequate to maintain a stable population. The Elizabeth River appeared to have lower productivity (1.00 fledgling/ active nest) compared to the other sites, but still adequate to maintain a stable population. However, this lower productivity rate may be related to sample size (only $\mathrm{n}=6$ nests). By inclusion of data from seven additional Elizabeth River nests, the productivity estimate increased to 1.28 fledglings/active nest, which is more than adequate to maintain a stable population. Osprey productivity rates are primarily driven by food availability and brood reduction, but could also be adversely affected by $p, p^{\prime}-\mathrm{DDE}$ and other 
contaminant burdens in osprey eggs.

Although there were no differences in productivity (i.e., number of eggs laid, hatching and fledging success) among sites, there were some notable changes in osprey nesting in ROCs. In 2000, only one osprey nesting pair was observed on Bear Creek off of Baltimore Harbor/Patapsco River, which is considered to contain the most highly toxic sediments in Baltimore Harbor (McGee et al., 1999). In 2011, at least four pairs were observed nesting on channel markers and power transmission towers. On the Anacostia River, only one pair was observed in 2000, but by 2011 there were at least four nesting attempts, two of which were successful. While it is tempting to conclude that decreasing contaminants in eggs could account for differences in productivity, temporal and site-specific differences in other factors (e.g., food availability, nest site quality/ availability, weather, predation, inexperienced breeders) could also contribute to fluctuations in fecundity (Levenson and Koplin, 1984; Stinson et al., 1987; Machmer and Ydenberg, 1989). Compared to 2000-2001, nest density slightly increased at all study sites (Baltimore Harbor/Patapsco River 1 nest/2.30 km² in 2000 vs. 1 nest/ $1.60 \mathrm{~km}^{2}$ current study; Anacostia/middle Potomac 1 nest $/ 4.7 \mathrm{~km} 2$ vs. 1 nest $/ 3.9 \mathrm{~km}^{2}$; Elizabeth River 1 nest $/ 4.7 \mathrm{~km}^{2}$ in 2001 vs. 1 nest/ $3.57 \mathrm{~km}^{2}$ in 2012).

It has been suggested that the collection of a sample egg may bias productivity rates. For some datasets, a difference has been noted in productivity between sampled and unsampled nests, and some investigators (Henny and Kaiser, 1996) adjust productivity to account for sample egg collection. However, in other studies no differences in productivity between sampled and unsampled nests have been noted (Rattner et al., 2004; Toschik et al., 2005). Nests at the Poplar Island reference site from which a sample egg was collected fledged 1.38 young, while unsampled nests from this site fledged 1.31 young. Unlike Henny and Kaiser (1996), Henny et al., 2004, the present study limited sampling to nests containing three or more eggs, which may account for this difference.

\subsection{Eggshell thickness}

Eggshell thickness in Chesapeake Bay ROCs was on average $0.514 \pm 0.054 \mathrm{~mm}$, which is close to the average pre-DDT-era value (0.505 mm, $\mathrm{n}=365$, Anderson and Hickey, 1970). In the 1970s, eggshell thickness on the Potomac River was about 19\% lower $(0.402-0.416 \mathrm{~mm})$ than the pre-DDT-era value (Wiemeyer et al., 1988). In the 1970s, Wiemeyer et al., 1988 found an association $(\mathrm{r}=-0.70)$ between $p, p^{\prime}$-DDE residues in osprey eggs and eggshell thickness. Notably, concentrations of organochlorine pesticides and metabolites (Table 2) are now well below the threshold associated with 10\% eggshell thinning (Wiemeyer et al., 1988). In fact, no significant relationship was observed between concentrations of p,p'-DDE and eggshell thickness in the 2011-2012 dataset.

\subsection{Contaminant exposure in Regions of Concern}

Residues of $p, p^{\prime}$-DDE on the middle Potomac River declined about 75\% between 1971-1977 and 2011 (3.1 $\mu \mathrm{g} / \mathrm{g}$ ww in the 1970s, Wiemeyer et al., 1988; $1.16 \mu \mathrm{g} / \mathrm{g}$ ww in 2000, Rattner et al., 2004, $0.73 \mu \mathrm{g} / \mathrm{g}$ ww, present study). Concentrations of $p, p^{\prime}$-DDE in eggs collected in other ROCs were low and did not seem to change in the past decade (Baltimore Harbor $0.443 \mu \mathrm{g} / \mathrm{g}$ ww in 2000 versus $0.553 \mu \mathrm{g} / \mathrm{g}$ ww in 2011; Elizabeth River $0.660 \mu \mathrm{g} / \mathrm{g}$ ww in 2001 versus $0.488 \mu \mathrm{g} / \mathrm{g}$ ww in 2012). Mean $p, p^{\prime}$-DDE concentrations in Chesapeake Bay $(<0.725 \mu \mathrm{g} / \mathrm{g}$ ww; Table 2$)$ remain lower than those reported in the most industrialized and urbanized segment of Delaware River between C\&D canal and Easton, PA (means < $1.77 \mu \mathrm{g} / \mathrm{g}$ ww; Toschik et al., 2005).

From a temporal perspective, $\mathrm{PCB}$ residues in osprey eggs from
Baltimore Harbor/Patapsco and Elizabeth Rivers remained unchanged over the decade. Notably, eggs collected from Curtis Creek (Baltimore Harbor) in 2011 contained the greatest PCB residues (12.9 and $35.0 \mu \mathrm{g} / \mathrm{g} \mathrm{ww}$ ), and were comparable or exceeded values reported across the Northeast U.S. in the 1970s (up to $23 \mu \mathrm{g} / \mathrm{g}$ ww; Wiemeyer et al., 1988). However, a 40\% decline in average total PCB concentrations was observed in eggs from the Anacostia/ middle Potomac ROC (Fig. 2). This suggests that PCB levels or their bioavailability in the osprey food web on the Anacostia/middle Potomac Rivers have decreased over the past decade. In support of this hypothesis, a reduction in total PCB concentrations in sediments has been reported for the Anacostia, where residues have declined by an order of magnitude over the past 25 years (Velinsky et al., 2011). Due to moderate biomagnification factors from fish to osprey eggs (e.g., 11 times; Henny et al., 2003), these changes in chlorinated biphenyl concentrations in sediments may be translated up the food web.

Coplanar PCBs have been associated with embryonic deformities and adverse reproductive effects along with other toxic responses in fish-eating birds (Rice et al., 2003; Su et al., 2014). There was no evidence of embryonic deformities or reproductive impairment in the present study. Despite differences in analytical methods and detection limits between this current study and Rattner et al. (2004), all TEQs were well below the threshold associated with cytochrome P450 induction in osprey nestlings (Elliott et al., 2001).

Over the past decade, congener patterns of PBDEs did not change dramatically, with BDE 47, 99, 100, 153 and 154 being the most prominent congeners in osprey eggs across all sites. However, total PBDEs declined by about $40 \%$. This is similar to a $55 \%$ decline reported by Henny and coworkers (2011) for osprey eggs collected on the Willamette River, Oregon. Since the last ecotoxicological study in the Chesapeake, the penta- and octa-BDE formulations have been phased out of use in the U.S. (end of 2004) (US EPA, 2014a). More recently, use of the deca-formulation has been curtailed (US EPA, 2014b). While the manufacturer and use of PBDEs in new consumer products has been banned, many long-lived goods containing these compounds remain in use and end up in landfills. Thus, it is unknown how quickly environmental levels may change in the food web in response to regulatory action (Chen and Hale, 2010; Zhang et al., 2014).

Notably, PBDE residues in osprey eggs collected along the Anacostia/middle Potomac Rivers in 2000 were over four times greater than those found at the reference site (Rattner et al., 2004), with the maximum values detected near the Blue Plains WWTP. Other studies (Henny et al., 2011) have shown that volume of discharge and distance from a WWTP may be reflected in contaminant concentrations in osprey eggs and are presumably responsible for the high residues of PBDEs found in eggs near Blue Plains.

The detection of PBDEs in osprey eggs in ROCs in 2000-2001 stimulated a series of studies examining the effects of flame retardants on raptorial birds (e.g., Fernie et al., 2005, 2006, 2008; McKernan et al., 2009; Rattner et al., 2013). These studies provided a context for placing field residue data into perspective. In controlled exposure studies, the presence of PBDE flame retardants in developing American kestrel (Falco sparverius) embryos have been associated with oxidative stress, DNA damage, delay in hatch time, shorter humerus length, reduced total thyroid weight and reproductive and courtship behavior changes in adults. In field studies, Chen et al. (2010) have estimated a biomagnification factor of 25.1 for total PBDEs in the osprey food web. Reduced osprey productivity was associated with PBDEs at concentrations exceeding $1000 \mathrm{ng} / \mathrm{g}$ ww in eggs from Oregon and Washington (Henny et al., 2009). These 
findings were suggested to be equivocal in a subsequent study (Henny et al., 2011). In the Chesapeake, the greatest residues of total PBDEs in osprey eggs $(0.928 \mu \mathrm{g} / \mathrm{g}$ in 2000 and $0.802 \mu \mathrm{g} / \mathrm{g}$ ww in 2011) approached the lowest-observed-adverse-effectlevel (LOAEL) of $1.8 \mu \mathrm{g} / \mathrm{g}$ ww for pipping and hatching success (McKernan et al., 2009), but there was no evidence of impaired hatching success or overall productivity in Chesapeake Bay ospreys. Many uncertainty factors (differences in species sensitivity and metabolism, exposure to mixtures of toxicants) and knowledge gaps for toxicity thresholds make extrapolations from the lab to the field difficult.

In place of PBDE formulations, alt-BFRs are now being manufactured and there are concerns regarding their potential persistence and bioaccumulation (de Wit et al., 2011; Stieger et al., 2014). Like PBDEs, these BFRs can leach into the environment and have been detected in piscivorous birds (Glaucous gulls Larus hyperboreus, Verreault et al., 2007; herring gulls Larus argentatus, Gauthier et al., 2007; white-tailed sea eagles Haliaeetus albicilla, Eulaers et al., 2014). Among the alt-BFRs, HBCD has been shown to cause endocrine and behavioral effects in captive American kestrels (Marteinson et al., 2011, 2012). Concentrations of HBCD in Chesapeake Bay osprey eggs were much lower than the HBCD toxicity thresholds determined to date. In this current study, $\alpha$-HBCD was detected most frequently in osprey egg samples, but at much lower concentrations than other locations, including the Norwegian Arctic (7.23-63.9 ng/g ww, Verreault et al., 2007 versus < MDL$3.72 \mathrm{ng} / \mathrm{g}$ ww in the present study). Our results reveal that mixtures of flame retardants are present in egg samples from the Chesapeake Bay, but the biological significance of these levels is unclear.

\subsection{DNA damage}

This study documents evidence of mild DNA damage in Baltimore Harbor/Patapsco and Anacostia/middle Potomac Rivers compared to the reference site, and also variations of $8-\mathrm{OH}-\mathrm{dG}$ concentrations between individuals. Xenobiotics including PCBs, PBDEs and even PAHs are known to increase reactive oxygen species in cells and can damage lipids, proteins and DNA. Mild oxidative stress has been detected in American kestrels (and to a lesser degree in common terns) in response to embryonic exposure to the penta-BDE commercial mixture DE-71 (Fernie et al., 2005; McKernan et al., 2009; Rattner et al., 2013). Osprey nestlings are exposed to a multitude of stressors, and may have adapted antioxidant defense mechanisms. Life history traits including trophic level and life span may influence their capability to tolerate oxidative stress leading to large variations in responses even between individuals (Costantini, 2008). Current evidence suggests that oxidative stress may impair immune function, longevity and reproduction (Costantini, 2008). Ultimately, damage to DNA may make the individual susceptible to disease progression and epigenetic effects that may be reflected in later generations (Cooke et al., 2003).

\section{Conclusions}

The present findings indicate that organochlorine pesticides and PBDE flame retardants continue to decline in osprey eggs in Chesapeake Bay, consistent with discontinuation of their use. Low levels of organochlorine pesticides were detected at all sites, well below the threshold associated with 10\% eggshell thinning. Interestingly, PBDE residues in eggs were greatest near the Blue Plains WWTP on the Potomac River, which suggests that wastewater discharge and sewage sludge are a source of continued input of PBDEs to the environment (LaGuardia et al., 2010). While total PCB concentrations declined at some sites, they remain high in Baltimore Harbor/Patapsco River and continue to drive fish consumption advisories in Chesapeake Bay (MDE, 2014; VDH, 2009). Overall, there were no apparent large-scale effects of the contaminants examined here on osprey productivity. The Bay osprey population continues to increase and productivity rates are at or have exceeded the threshold to maintain a stable population. Since reaching their nadir in the 1970s the Chesapeake Bay osprey population has demonstrated its resilience in the face of anthropogenic threats. Although osprey productivity appears stable at the population level, DNA damage assays suggest more subtle biochemical and cellular effects that could have consequences on the fitness of some individuals.

\section{Acknowledgments}

The authors thank C.P. Guy and C.R. Callahan of the U.S. Fish and Wildlife Service, D.D. Day and J.S. Hatfield of the USGS-PWRC for assistance with various phases of this study. We thank Drs. Charles J. Henny and Bryan D. Watts for providing valuable comments on a draft of this manuscript. This work was primarily supported by the USGS-Chesapeake Bay Program. Any use of trade, product, or firm names is for descriptive purposes only and does not imply endorsement by the U.S. government.

\section{Appendix A. Supplementary data}

Supplementary data related to this article can be found at http:// dx.doi.org/10.1016/j.envpol.2015.05.026.

\section{References}

Anderson, D.W., Hickey, J.J., 1970. Eggshell changes in certain North American birds Proc. Int. Ornithol. Cong. 15, 514-540.

Bart, J., Robson, D.S., 1982. Estimating survivorship when the subjects are visited periodically. Ecology 63, 1078-1090.

Blus, L.J., 1984. DDE in birds' eggs: comparison of two methods for estimating critical levels. Wilson Bull. 96, 268-276.

Blus, L.J., 2011. DDT, DDD, and DDE in birds. In: Beyer, W.N., Meador, J.P. (Eds.), Environmental Contaminants in Biota: Interpreting Tissue Concentrations, 2nd ed. CRC Press, Taylor \& Francis Group, Boca Raton, FL, USA, pp. 425-444.

Chen, D., LaGuardia, M.J., Harvey, E., Amaral, M., Wohlfort, K., Hale, R.C., 2008 Polybrominated diphenyl ethers in peregrine falcon (Falco peregrinus) eggs from the Northeastern U.S. Environ. Sci. Technol. 42, 7594-7600.

Chen, D., Hale, R.C., 2010. A global review of polybrominated diphenyl ether flame retardant contamination in birds. Environ. Int. 36, 800-811.

Chen, D., Hale, R.C., Watts, B.D., LaGuardia, M.J., Harvey, E., Mojica, E.K., 2010. Species-specific accumulation of polybrominated diphenyl ether flame retardants in birds of prey from the Chesapeake Bay region, USA. Environ. Pollut. 158, 1883-1889.

Chesapeake Bay Executive Order, 2009. Chesapeake Bay Protection and Restoration. Office of the Press Secretary. Available. http://executiveorder.chesapeakebay. net/EO/file.axd?file $=2009 \% 2 \mathrm{f} \% 2 \mathrm{fChesapeake+Executive+Order.pdf}$ (accessed 27.03.15).

Cooke, M.S., Evans, M.D., Dizdaroglu, M., Lunec, J., 2003. Oxidative DNA damage: mechanisms, mutation and disease. FASEB J. 17, 1195-1214.

Costantini, D., 2008. Oxidative stress in ecology and evolution: lessons from avian studies. Ecol. Lett. 11, 1238-1251.

de Wit, C.A., Kierkegaard, A., Ricklund, N., Sellström, U., 2011. Emerging brominated flame retardants in the environment. In: Eljarrat, E., Barceló, D. (Eds.), Brominated Flame Retardants, The Handbook of Environmental Chemistry, vol. 16 Heidelberg, Germany, 241-286.

Elliott, J.E., Wilson, L.K., Henny, C.J., Trudeau, S.F., Leighton, F.A., Kennedy, S.W. Cheng, K.M., 2001. Assessment of biological effects of chlorinated hydrocarbons in osprey chicks. Environ. Toxicol. Chem. 20, 866-879.

Eulaers, I., Jaspers, V.L.B., Halley, D.J., Lepoint, G., Nygård, T., Pinxten, R., Covaci, A. Eens, M., 2014. Brominated and phosphorous flame retardants in white-tailed eagle Haliaeetus albicilla nestlings: bioaccumulation and associations with dietary proxies $\left(\delta^{13} \mathrm{C}, \delta^{15} \mathrm{~N}\right.$ and $\left.\delta^{34} \mathrm{~S}\right)$. Sci. Tot. Environ. 478, 48-57.

Fernie, K.J., Shutt, J.L., Mayne, G., Hoffman, D., Letcher, R.J., Drouillard, K.G., Ritchie, I.J., 2005. Exposure to polybrominated diphenyl ethers (PBDEs): changes in thyroid, vitamin A, glutathione homeostasis, and oxidative stress in American kestrels (Falco sparverius). Toxicol. Sci. 88, 375-383.

Fernie, K.J., Shutt, J.L., Ritchie, I.J., Letcher, R.J., Drouillard, K., Bird, D.M., 2006 Change in the growth, but not the survival, of American kestrels (Falco sparverius) exposed to environmentally relevant polybrominated diphenyl ethers. 
J. Toxicol. Environ. Health A 69, 1541-1554.

Fernie, K.J., Shutt, J.L., Letcher, R.J., Ritchie, IJ., Sullivan, K., Bird, D.M., 2008. Changes in reproductive courtship behaviors of adult American kestrels (Falco sparverius) exposed to environmentally relevant levels of the polybrominated diphenyl ether mixture, DE-71. Toxicol. Sci. 102, 171-178.

Gauthier, L.T., Hebert, C.E., Weseloh, D.V.C., Letcher, R.J., 2007. Current-use flame retardants in the eggs of herring gulls (Larus argentatus) from the Laurentian Great Lakes. Environ. Sci. Technol. 41, 4561-4567.

Grove, R.A., Henny, C.J., Kaiser, J.L., 2009. Osprey: worldwide sentinel species for assessing and monitoring environmental contamination in rivers, lakes, reservoirs and estuaries. J. Toxicol. Environ. Health B Crit. Rev. 12, 25-44.

Heinz, G.H., Stebbins, K.R., Klimstra, J.D., Hoffman, D.J., 2009. A simplified method for correcting contaminant concentrations in eggs for moisture loss. Environ. Toxicol. Chem. 28, 1425-1428.

Helsel, D.R., 2005. Nondetects and Data Analysis Statistics for Censored Environmental Data. John Wiley \& Sons, Inc., Hoboken. NJ, USA.

Henny, C.J., Smith, M.M., Stotts, V.D., 1974. The 1973 distribution and abundance of breeding ospreys in the Chesapeake Bay. Chesap. Sci. 15, 125-133.

Henny, C.J., Kaiser, J.L., 1996. Osprey population increase along the Willamette River Oregon and the role of utility structures, 1976-1993. In: Bird, D.M. Varland, D.E., Negro, J.J. (Eds.), Raptors in Human Landscapes. Academic Press Ltd., London, pp. 97-108.

Henny, C.J., Kaiser, J.L., Grove, R.A., Bently, V.R., Elliott, J.E., 2003. Biomagnification factors (fish to osprey eggs from Willamette River, Oregon, U.S.A.) for PCDDs, PCDFS, PCBS and OC pesticides. Environ. Monit. Assess. 84, 275-315.

Henny, C.J., Grove, R.A., Kaiser, J.L., Bentley, V.R., 2004. An evaluation of osprey eggs to determine spatial residue patterns and effects of contaminants along the lower Columbia River, U.S.A. In: Chancellor, R.D., Meyburg, B.U. (Eds.), Raptors Worldwide. WWGBP/MME, Budapest, Hungary, pp. 369-388.

Henny, C.J., Kaiser, J.L., Grove, R.A., Johnson, B.L., Letcher, R.J., 2009. Polybrominated diphenyl ether flame retardants in eggs may reduce reproductive success of ospreys in Oregon and Washington, USA. Ecotoxicology 18, 802-813.

Henny, C.J., Grove, R.A., Kaiser, J.L., Johnson, B.L., 2010. North American osprey populations and contaminants: historic and contemporary perspectives. J. Toxicol. Environ. Health B Crit. Rev. 13, 579-603.

Henny, C.J., Grove, R.A., Kaiser, J.L., Johnson, B.L., Furl, C.V., Letcher, R.J., 2011 Wastewater dilution index partially explains observed polybrominated flame retardant concentrations in osprey eggs from Columbia River Basin, 2008-2009. Ecotoxicology 20, 682-697.

La Guardia, M.J., Hale, R.C., Harvey, E., 2007. Evidence of debromination of decabromodiphenyl ether (BDE-209) in biota from a wastewater receiving stream. Environ. Sci. Technol. 41, 6663-6670.

La Guardia, M.J., Hale, R.C., Harvey, E., Chen, D., 2010. Flame-retardants and other organohalogens detected in sewage sludge by electron capture negative ion mass spectrometry. Environ. Sci. Technol. 44, 4658-4664.

La Guardia, M.J., Hale, R.C., Newman, B., 2013. Brominated flame-retardants in subSaharan Africa: burdens in inland and coastal sediments of the eThekwin metropolitan municipality, South Africa. Environ. Sci. Technol. 47, 9643-9650.

Lazarus, R.S., Rattner, B.A., Brooks, B.W., Du, B., McGowan, P.C., Blazer, V.S. Ottinger, M.A., 2015. Exposure and food web transfer of pharmaceuticals in ospreys (Pandion haliaetus): predictive model and empirical data. Integ. Environ. Assess. Manag. 11, 118-129.

Levenson, H., Koplin, J.R., 1984. Effects of human activity on productivity of nesting ospreys. J. Wild. Manage 48, 1374-1377.

Machmer, M.M., Ydenberg, R.C., 1989. Weather and osprey foraging energetics. Can. J. Zool. 68, 40-43.

Marteinson, S.C., Kimmins, S., Letcher, R.J., Palace, V.P., Bird, D.M., Ritchie, I.J. Fernie, K.J., 2011. Diet exposure to technical hexabromocyclododecane (HBCD) affects testes and circulating testosterone and thyroxine levels in American Kestrels (Falco sparverius). Environ. Res. 111, 1116-1123.

Marteinson, S.C., Bird, D.M., Letcher, R.J., Sullivan, K.M., Ritchie, I.J., Fernie, K.J., 2012 Dietary exposure to technical hexabromocyclododecane (HBCD) alters courtship, incubation and parental behaviors in American Kestrels (Falco sparverius). Chemosphere 89, 1077-1083.

Mayfield, H., 1961. Nesting success calculated from exposure. Wilson Bull. 73, 255-261.

McGee, B.L., Fisher, D.J., Yonkos, L.T., Ziegler, G.P., Turley, S., 1999. Assessment of sediment contamination, acute toxicity, and population viability of the estuarine amphipod Leptocheirus plumulosus in Baltimore Harbor, Maryland, USA. Enivron. Toxicol. Chem. 18, 2151-2160.

McKernan, M.A., Rattner, B.A., Hale, R.C., Ottinger, M.A., 2009. Toxicity of polybrominated diphenyl ethers (DE-71) in chicken (Gallus gallus), mallard (Anas platyrhynchos), and American kestrel (Falco sparverius) embryos and hatchlings. Environ. Toxicol. Chem. 28, 1007-1017.

(MDE) Maryland Department of the Environment, 2014. Guidelines for Recreationally Caught Fish Species in Maryland. Available. http://www.mde.state.md. us/assets/document/fish/advisory_summary.pdf (accessed 03.02.15.)

Poole, A.F., 1989. Ospreys: a Natural and Unnatural History. Cambridge University Press, New York.

Postupalsky, S., 1977. A critical review of problems in calculating osprey reproductive success. In: Ogden, J.C. (Ed.), Transactions North American Osprey Research Conference, U.S. Department of the Interior National Park Service Transactions and Proceedings Series No. 2. College of William and Mary,
Williamsburg, VA, pp. 1-11, 1972.

Rattner, B.A., McGowan, P.C., Golden, N.H., Hatfield, J.S., Toschik, P.C., Lukei, R.F. Hale, R.C., Schmitz-Afonso, I., Rice, C.P., 2004. Contaminant exposure and reproductive success of ospreys (Pandion haliaetus) nesting in Chesapeake Bay regions of concern. Arch. Environ. Contam. Toxicol. 47, 126-140.

Rattner, B.A., McGowan, P.C., 2007. Potential hazards of environmental contaminants to avifauna residing in the Chesapeake Bay estuary. Waterbirds 30 (Sp 1), 63-81.

Rattner, B.A., Lazarus, R.S., Heinz, G.H., Karouna-Renier, N.K., Schultz, S.L., Hale, R.C. 2013. Comparative embryotoxicity of a pentabrominated diphenyl ether mixture to common terns (Sterna hirundo) and American kestrels (Falco sparverius). Chemosphere 92, 441-447.

Rice, C.P., O'Keefe, PW. Kubiak, T., 2003. Sources, pathways and effects of PCBs dioxins and dibenzofurans. In: Hoffman, D.J., Rattner, B.A., Bruton Jr., G.A., Cairns Jr., J. (Eds.), Handbook of Ecotoxicology. Lewis Publishers, Boca Raton, FL, pp. 501-573.

Schaadt, C.P., Bird, D.M., 1993. Sex-specific growth in ospreys: the role of sexual size dimorphism. Auk 110, 900-910.

Spitzer, P.R., 1980. Dynamics of a Discrete Coastal Breeding Population of Ospreys in the Northeastern United States during the Period of Decline and Recovery, 1969-1978 (Ph.D. thesis). Cornell Univ., Ithaca, NY.

Spitzer, P.R., Poole, A.F., Scheibel, M., 1983. Initial recovery of breeding ospreys in the region between New York City and Boston. In: Bird, D.M. (Ed.), Biology and Management of Bald Eagles and Ospreys. Harpell Press, Ste, Anne de Bellevue, Quebec, pp. 231-241.

Steenhof, K., Newton, I., 2007. Assessing nesting success and productivity. In: Bird, D.M., Bildstein, K.L. (Eds.), Raptor Research and Management Techniques. Hancock House, Surrey, British Columbia, Canada, pp. 181-192.

Stieger, G., Scheringer, M., Ng, C.A., Hungerbühler, K., 2014. Assessing the persistence, bioaccumulation potential and toxicity of brominated flame retardants: data availability and quality for 36 alternative brominated flame retardants. Chemosphere 116, 118-123.

Stinson, C.H., Lauthner, J., Ray, R.T., 1987. The effect of weather conditions on behavior of ospreys in northwestern Washington. Can. J. Zool, 65, 2116-2118.

Su, H., Wu, F., Zhang, R., Zhao, X., Mu, Y., Feng, C., Giesy, J.P., 2014. Toxicity reference values for protecting aquatic birds in China from the effects of polychlorinated biphenyls. Rev. Environ. Contam. Toxicol. 230, 59-82.

Toschik, P.C., Rattner, B.A., McGowan, P.C., Christman, M.C., Carter, D.B., Hale, R.C., Matson, C.W., Ottinger, M.A., 2005. Effects of contaminant exposure on reproductive success of ospreys (Pandion haliaetus) nesting in Delaware River and Bay, USA. Environ. Toxicol. Chem. 24, 617-628.

Turle, R., Norstrom, R.J., Collins, B., 1991. Comparison of PCB quantification methods: re-analysis of archived specimens of herring gull eggs from the Great Lakes. Chemosphere 22, 201-213.

(US EPA) U.S. Environmental Protection Agency, 1994. Chesapeake Bay Basinwide Toxics Reduction Strategy Reevaluation Report, p. 192. U.S. EPA CBP/TRS 117/94, Annapolis, MD.

(US EPA) United States Environmental Protection Agency, U.S. Geological Survey, U.S. Fish and Wildlife Service, 2012. Toxic Contaminants in the Chesapeake Bay and its Watershed: Extent and Severity of Occurrence and Potential Biological Effects. U.S. EPA Chesapeake Bay Program Office, Annapolis, MD, p. 175.

(US EPA) United States Environmental Protection Agency, 2014a. Polybrominated Diphenylethers (PBDEs) Significant New Use Rules. Available. http://www.epa. gov/oppt/existingchemicals/pubs/qanda.html (accessed 03.02.15.).

(US EPA) United States Environmental Protection Agency, 2014b. DecaBDE Phaseout Initiative. Available. http://www.epa.gov/oppt/existingchemicals/pubs/ actionplans/deccadbe.html (accessed 03.02.15.).

van den Berg, M., Birnbaum, L., Bosveld, A.T.C., Brunström, B., Cook, P., Feeley, M. Giesy, J.P. Hanberg, A., Hasegawa, R., Kennedy, S.W., Kubiak, T., Larsen, J.C., Rolaf van Leeuwen, F.X., Djien Liem, A.K., Nolt, C., Peterson, R.E., Poellinger, L., Safe, S., Schrenk, D., Tillitt, D., Tysklind, M., Younes, M., Waern, F., Zacharewski, T., 1998. Toxic equivalency factors (TEFs) for PCBs, PCDDs, PCDFs for humans and wildlife. Environ. Health Perspect. 106, 775-792.

van den Berg, M., Birnbaum, L.S., Denison, M., De Vito, M., Farland, W., Feeley, M., Fiedler, H., Hakansson, H., Hanberg, A., Haws, L., Rose, M., Safe, S., Schrenk, D., Tohyama, C., Tritscher, A., Tuomisto, J., Tysklind, M., Walker, N., Peterson, R.E., 2006. The 2005 world health organization reevaluation of human and mammalian toxic equivalency factors for dioxins and dioxin-like compounds. Toxicol. Sci. 93, 223-241.

Velinsky, D.J., Riedel, G.F., Ashley, J.T.F., Cornwell, J.C., 2011. Historical contamination of the Anacostia river, Washington, D.C. Environ. Monit. Assess. 183, 307-328.

Verreault, J., Gebbink, W.A., Gauthier, L.T., Gabrielsen, G.W., Letcher, R.J. 2007. Brominated flame retardants in glaucous gulls from the Norwegian Artic: more than just an issue of polybrominated diphenyl ethers. Environ. Sci. Technol. 41, 4925-4931.

(VDH) Virginia Department of Health, 2009. Consumption Advisories and Restrictions in Effect of Virginia Waterways. Available. http://www.vdh.state.va. us/epidemiology/DEE/PublichealthToxicology/Advisories (accessed 03.02.15.).

Watts, B.D. Byrd, M.A., Watts, M.U., 2004. Status and distribution of breeding ospreys in Chesapeake Bay: 1995-1996. J. Raptor Res. 38, 47-54.

Watts, B.D., Paxton, B.J., 2007. Ospreys of the Chesapeake Bay: population recovery, ecological requirements, and current threats. Waterbirds 30 (Sp 1), 39-49.

Wiemeyer, S.N., 1971. Reproductive success of Potomac River ospreys, 1970. Chesap. 
Sci. 12, 278-280.

Wiemeyer, S.N., Bunk, C.M., Krynitsky, A.J., 1988. Organochlorine pesticides, polychlorinated biphenyls, and mercury in osprey eggs -1970-79-and their relationships to shell thinning and productivity. Arch. Environ. Contam. Toxicol. 17, 767-787.
Zhang, R., Guo, J., Wu, F., Mu, Y., Giesy, J.P., Chang, H., Zhao, X., Feng, C., 2014. Toxicity reference values for polybrominated diphenyl ethers: risk assessment for predatory birds and mammals from two Chinese lakes. Rev. Environ. Contam. Toxicol. 229, 111-137. 


\section{Supporting Information}

Title: Decadal re-evaluation of contaminant exposure and productivity in ospreys (Pandion haliaetus) nesting in Chesapeake Bay Regions of Concern

Authors: Rebecca S. Lazarus a,b, Barnett A. Rattner ${ }^{a *}$, Peter C. McGowan ${ }^{c}$, Robert C. Hale ${ }^{d}$, Sandra L. Schultz ${ }^{\mathrm{a}}$, Natalie K. Karouna-Renier ${ }^{\mathrm{a}}$, Mary Ann Ottinger ${ }^{\mathrm{b}, 1}$

${ }^{a}$ U.S. Geological Survey, Patuxent Wildlife Research Center, Beltsville, Maryland 20705, USA

${ }^{\mathrm{b}}$ Marine-Estuarine Environmental Sciences Program and Department of Animal and Avian Sciences, University of Maryland, College Park, MD 20742, USA

${ }^{c}$ U.S. Fish and Wildlife Service, Chesapeake Bay Field Office, Annapolis, Maryland 21401, USA

${ }^{\mathrm{d}}$ Virginia Institute of Marine Science, College of William and Mary, Gloucester Point, VA 23062 USA

*To whom correspondence may be addressed:

Barnett A. Rattner, Ph.D.

Patuxent Wildlife Research Center, U.S. Geological Survey

c/o BARC-East, Building 308

10300 Baltimore Avenue

Beltsville, Maryland 20705, USA

Telephone: 1-301-497-5671; FAX: 1-301-497-5624

Email: brattner@usgs.gov

${ }^{1}$ Present Address: Department of Biology and Biochemistry, University of Houston, Houston, TX 77004, USA

Number of pages: 1 (this cover page excluded)

Number of tables: 1 
Table S1. Concentrations of $p, p^{\prime}$-DDE, total PCBs and PBDEs in archived eggs analyzed in 2000-2001 and re-analyzed in 2011-2012 ${ }^{\mathrm{a}}$

\begin{tabular}{|c|c|c|c|c|c|c|c|c|}
\hline Sample ID & Site & $\begin{array}{l}\text { Analytical } \\
\text { Laboratory }\end{array}$ & $\begin{array}{l}p, p^{\prime}-\mathrm{DDE} \\
(\mu \mathrm{g} / \mathrm{g} \mathbf{w w})\end{array}$ & $\begin{array}{c}p, p^{\prime}-\mathrm{DDE} \\
\text { Percent Difference }\end{array}$ & $\begin{array}{c}\text { Total PCBs } \\
(\mu \mathrm{g} / \mathrm{g} \text { ww) }\end{array}$ & $\begin{array}{c}\text { Total PCBs } \\
\text { Percent Difference }\end{array}$ & $\begin{array}{l}\text { Total PBDEs } \\
\text { (ng/g ww) }\end{array}$ & $\begin{array}{c}\text { Total PBDEs } \\
\text { Percent Difference }\end{array}$ \\
\hline \multirow{2}{*}{ BHRC3-1 } & \multirow{2}{*}{ Baltimore Harbor/Patapsco/River } & Hale 2011 & 0.926 & \multirow{2}{*}{56.2} & 7.75 & \multirow{2}{*}{38.3} & 243 & \multirow{2}{*}{11.5} \\
\hline & & GERG 2000 & 0.519 & & 11.4 & & 272 & \\
\hline \multirow{2}{*}{ BHCC1-1 } & \multirow{2}{*}{ Baltimore Harbor/Patapsco/River } & Hale 2011 & 0.453 & \multirow{2}{*}{35.6} & 5.07 & \multirow{2}{*}{4.14} & 394 & \multirow{2}{*}{15.5} \\
\hline & & GERG 2000 & 0.316 & & 4.86 & & 337 & \\
\hline \multirow{2}{*}{ BHORB1-1 } & \multirow{2}{*}{ Baltimore Harbor/Patapsco/River } & Hale 2011 & 1.955 & \multirow{2}{*}{110.2} & 16.6 & \multirow{2}{*}{68.7} & & \\
\hline & & GERG 2000 & 0.566 & & 8.10 & & & \\
\hline \multirow{2}{*}{ BНBР7-1 } & \multirow{2}{*}{ Baltimore Harbor/Patapsco/River } & Hale 2011 & 0.758 & \multirow{2}{*}{49.9} & 7.94 & \multirow{2}{*}{12.0} & & \\
\hline & & GERG 2000 & 0.455 & & 7.04 & & & \\
\hline \multirow{2}{*}{ BHSC5-1 } & \multirow{2}{*}{ Baltimore Harbor/Patapsco/River } & Hale 2011 & 0.790 & \multirow{2}{*}{49.3} & 10.3 & \multirow{2}{*}{2.16} & & \\
\hline & & GERG & 0.478 & & 10.0 & & & \\
\hline \multirow{2}{*}{ PRSNRL-1 } & \multirow{2}{*}{ Anacostia/middle Potomac Rivers } & Hale 2011 & 1.100 & \multirow{2}{*}{21.2} & 7.42 & \multirow{2}{*}{10.0} & & \\
\hline & & GERG 2000 & 0.889 & & 8.20 & & & \\
\hline \multirow{2}{*}{ PRDC-2 } & \multirow{2}{*}{ Anacostia/middle Potomac Rivers } & Hale 2011 & 1.720 & \multirow{2}{*}{26.8} & 7.01 & \multirow{2}{*}{30.6} & & \\
\hline & & GERG 2000 & 1.314 & & 9.55 & & & \\
\hline \multirow{2}{*}{ PR88-1 } & \multirow{2}{*}{ Anacostia/middle Potomac Rivers } & Hale 2011 & 1.513 & \multirow{2}{*}{26.2} & 9.44 & -0 & & \\
\hline & & GERG 2000 & 1.163 & & 9.02 & 4.58 & & \\
\hline ת מסעמח & $\Gamma 1$. & Hale 2012 & 0.650 & 20 & 4.89 & 200 & 149 & 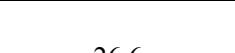 \\
\hline ERWBP-3 & Elizabeth River & GERG 2001 & 0.448 & 36.8 & 3.58 & 30.8 & 195 & 26.6 \\
\hline CDQ 1 & Flizgheth Piyer & Hale 2012 & 1.370 & 322 & 11.6 & 411 & 174 & 353 \\
\hline ER $8-1$ & Elizabeth River & GERG 2001 & 0.990 & 32.2 & 7.65 & 41.1 & 248 & 35.3 \\
\hline CINW 1 & Flizaheth River & Hale 2012 & 0.911 & 428 & 1.12 & 185 & 153 & 073 \\
\hline$C 1 N W-1$ & Elizabeth Kiver & GERG 2001 & 0.590 & 42.8 & 1.35 & 18.3 & 154 & 0.13 \\
\hline
\end{tabular}

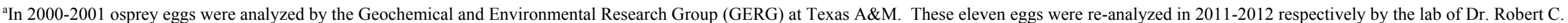
Hale at the Virginia Institute of Marine Science. In 2000-2001, only a subset of the eggs were analyzed for PBDEs, which limited the number of samples $(\mathrm{n}=5)$ that could be compared. Percent difference $=$ (absolute difference/mean) x $100 \%$. 